bioRxiv preprint doi: $h$ ttps://doi org/10.1101/2021.03 22 436462: this version posted March 22.2021 . The copyriaht holder for this preprint (which was not certified by peer review) is the author/funder, who has granted bioRxiv a license to display the preprint in perpetuity. It is made available under aCC-BY-NC-ND 4.0 International license.

\title{
Protein-protein docking analysis reveals efficient binding and complex formation between the human nuclear transport proteins
}

Shravan B. Rathod

Department of Chemistry, Smt. S. M. Panchal Science College, Talod, Gujarat, India

Email: shravanathorizon93@gmail.com

ORCID ID: 0000-0002-1870-2508

Graphical abstract

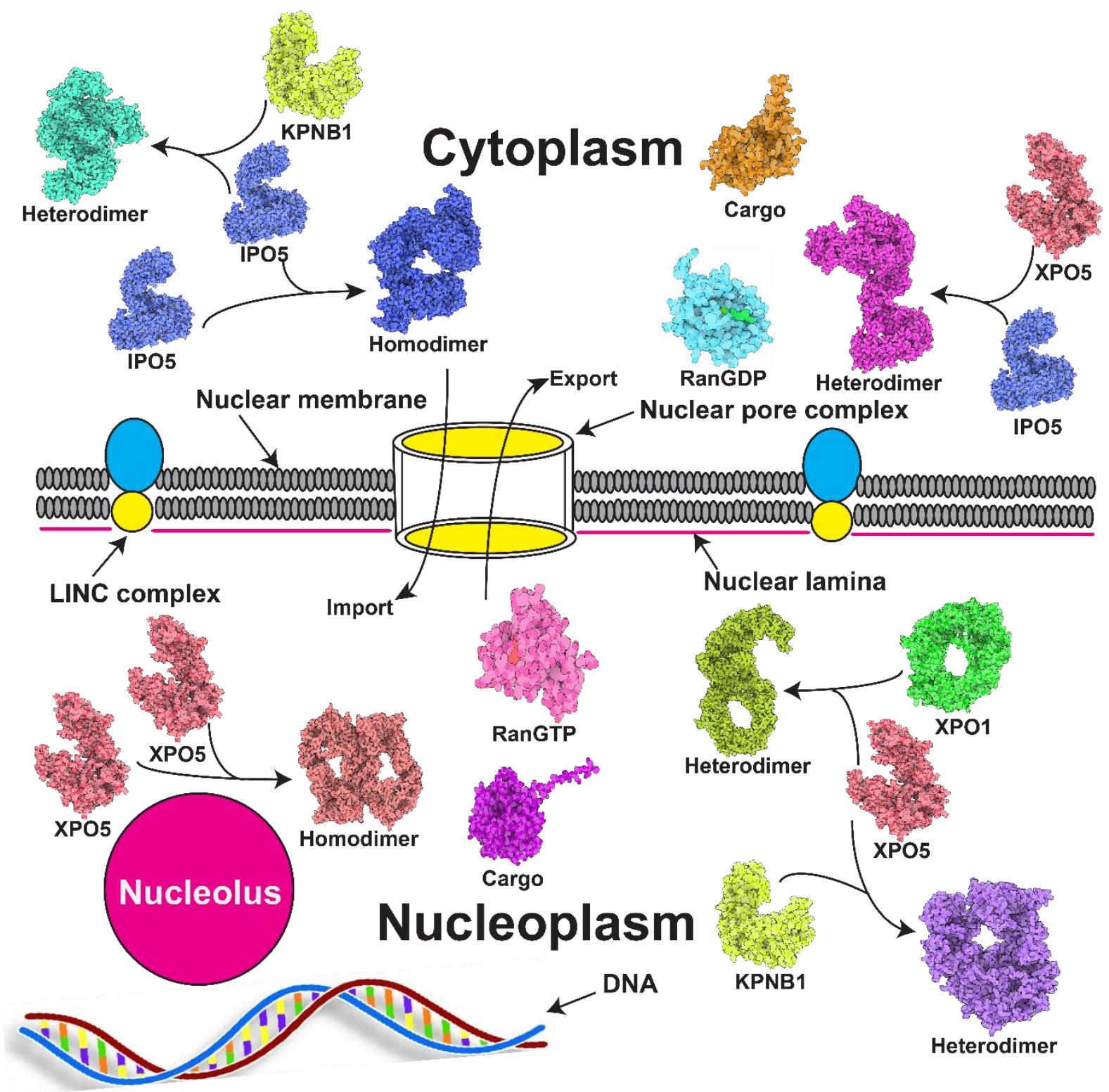

Possible complex formation between the human nuclear transport proteins. 


\section{Abstract}

The nuclear protein transport between the nucleus and cytosol can be considered a core process of cell regulation. Specially designed proteins in nature such as importins, exportins, and some other transporters facilitate this transport in the cell and control the cellular processes. Prior to cargo transports, the transport proteins first recognize the Nuclear localization signals (NLSs) and Nuclear export signals (NESs) of cargo proteins. NLSs and NESs are short peptides that have specific residues which help to locate them on the groove of transport proteins. However, this transport through the Nuclear pore complexes (NPCs) is not possible without the energy supplying protein, RanGTP (RAsrelated nuclear protein guanosine-5-triphosphate). In addition to this, transport proteins bind with other similar protein subunits along with RanGTP to transport cargos. Hence, protein-protein binding is a vital step for the cargo movement. Here, I investigated possible bindings between 12 human nuclear transport proteins using protein-protein docking algorithm. Furthermore, the binding energy of docked complexes have been calculated and compared with the experimentally resolved complexes. Among total 78 possible complexes (12 homodimers and 66 Heterodimers), IPO13-IPO13 and KPNA6-TNPO3 were found to have the highest stability. Another complexes such as IPO4-IPO5, IPO4-IPO9, IPO9IPO13, IPO9-KPNA6, IPO13-KPNA6, and IPO13-XPO5 have the binding energy greater than the -600 $\mathrm{kJ} / \mathrm{mol}$ which indicates the stable complex formation.

\section{Keywords}

Molecular docking, Protein-protein interactions, Nuclear transport proteins, Importin, Exportin, Transportin, Binding affinity, Nuclear localization signal

\section{Introduction}

Cargo transportation between the nucleus and cytoplasm is an essential process for the cellular regulation and plays critical role in diverse physiological mechanisms such as cellular signal transduction, gene expression, and cell differentiation (Yun Hak Kim et al., 2017; Yasuhara et al., 2009). In eukaryotic cells, nuclear and cytoplasmic contents are physically separated by the lipid bilayer of nuclear envelope. Envelope has a large number of Nuclear pore complexes (NPCs) through which many molecular components make their journey between the nucleoplasm and cytoplasm. NPCs are composed of the assembly of proteins called nucleoporins (Frey \& Görlich, 2007; Kramer et al., 2008). Large and polar proteins cannot be transported via the diffusion process hence some selective transporters help them to commute between the cytoplasm and nucleus through NPCs (Fried \& Kutay, 2003; Panté \& Kann, 2002).

Transporters (importins and exportins) recognize the specific sequence to bind in cargo proteins called Nuclear localization signal (NLS) or Nuclear export signal (NES) and form a complex to transport them at a certain spot in the nucleus or cytoplasm. But, this is not the full story because to drive these processes, another important protein called RanGTP (RAs-related nuclear protein guanosine-5'triphosphate) binds to the transporter and plays a significant role to transport cargos (Okada et al., 2008). Hence, the complex formation between the cargos, transporters, and RanGTP is an inevitable step in protein transports.

It is possible that in the cytoplasmic and nucleoplasmic molecular crowding, the transporters can randomly bind with each other and form a homo- or heterodimer. Additionally, in pathophysiological conditions, they can interfere with other components and disrupt the cell homeostasis. Here, I analyzed 12 human nuclear transport proteins for their binding affinity to form complexes (homodimer and heterodimers) with each other using protein-protein molecular docking tools. Binding energy of these complexes were evaluated using Protein-protein interactions (PPIs) tools and validated using experimentally solved crystal structures of protein-protein complexes which are available in Protein data bank (PDB). Additionally, Electrostatic potential (ESP) of each protein was obtained to get further insight into protein-protein binding. Results indicate that these proteins can bind efficiently and form stable complexes. 
A

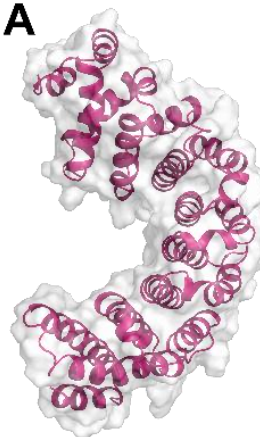

IPO4

E

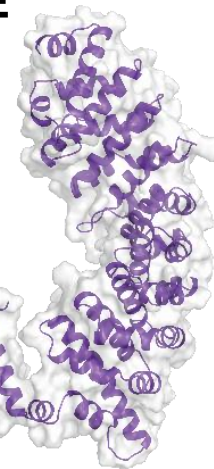

KPNA1

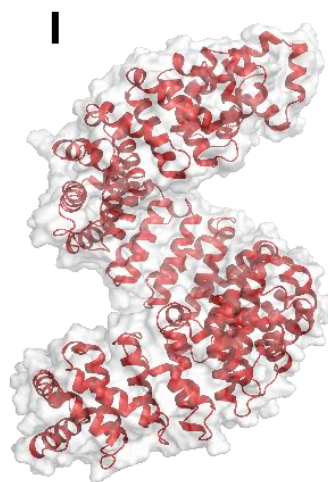

TNPO1

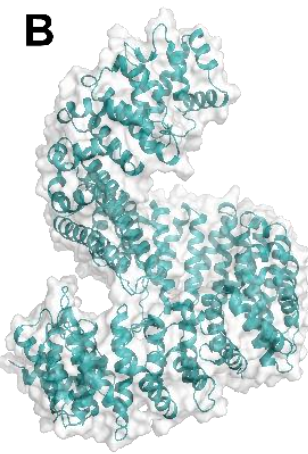

IPO5

$\mathbf{F}$

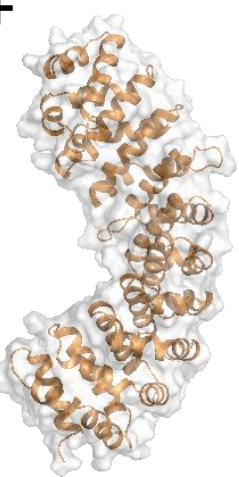

KPNA4

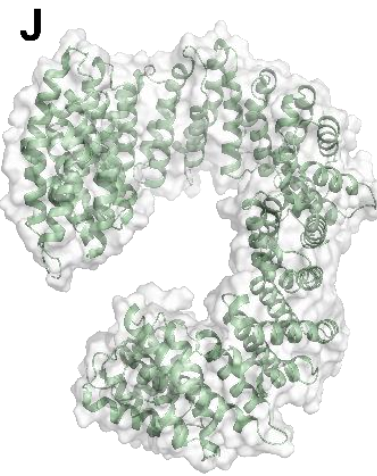

TNPO3

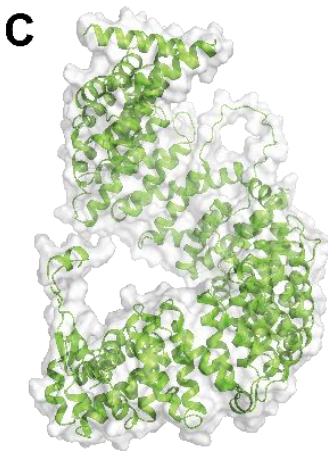

IPO9

G

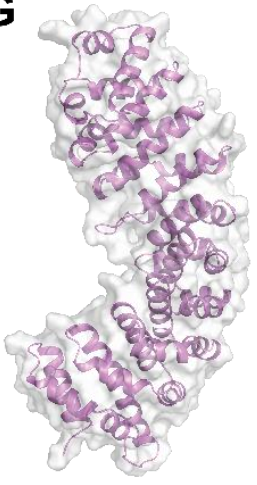

KPNA6

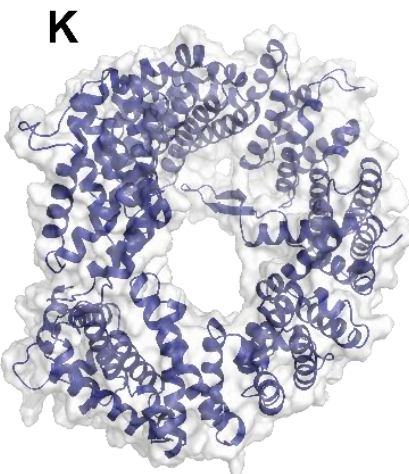

XPO1

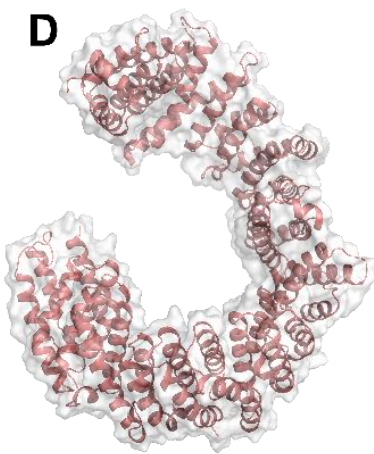

IP013

H

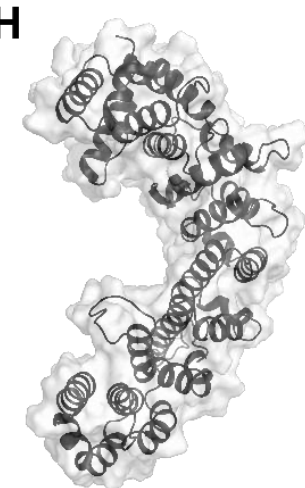

KPNB1

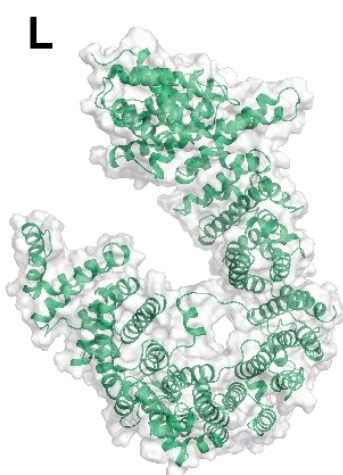

XPO5

Figure 1. Cartoon and surface representation of 12 human nuclear transport proteins.

\section{Materials and methods}

\section{Protein preparation}

The crystal structures of 12 proteins were retrieved from the PDB database (https://www.rcsb.org/). Only human nuclear proteins were selected and preferred on the basis of their high resolution structures with zero mutations. Heteroatoms such as solvent molecules and ligands were removed during protein preparation in PyMOL (Schrödinger LLC, 2010). Missing hydrogens in protein structures were added using PyMOL. PDB codes, sequence length, and crystallographic resolution of proteins are shown in Table 1 whereas Figure 1 illustrates the structure of 12 human nuclear transport proteins. 
bioRxiv preprint doi: https://doi.org/10.1101/2021.03.22.436462; this version posted March 22, 2021. The copyright holder for this preprint (which was not certified by peer review) is the author/funder, who has granted bioRxiv a license to display the preprint in perpetuity. It is made available under aCC-BY-NC-ND 4.0 International license.

Table 1. Proteins and their amino acid sequence length (chain length), PDB code, and crystallographic resolution.

\begin{tabular}{|c|c|c|c|c|}
\hline Protein & Name & Sequence length & PDB code & Resolution $(\AA)$ \\
\hline IPO4 & Importin-4 & 416 & $5 X \mathrm{XK}$ & 3.22 \\
\hline IPO5 & Importin-5 & 1096 & 6XTE & 2.27 \\
\hline IPO9 & Importin-9 & 1041 & $6 \mathrm{~N} 1 \mathrm{Z}$ & 2.70 \\
\hline IP013 & Importin-13 & 963 & $2 X W U$ & 2.80 \\
\hline KPNA1 & Karyopherin subunit $\alpha-1$ & 450 & $2 J D Q$ & 2.20 \\
\hline KPNA4 & Karyopherin subunit $\alpha-4$ & 421 & 4UAE & 2.70 \\
\hline KPNA6 & Karyopherin subunit $\alpha-6$ & 479 & 4UAD & 2.42 \\
\hline KPNB1 & Karyopherin subunit $\beta-1$ & 442 & 1F59 & 2.80 \\
\hline TNPO1 & Transportin-1 & 890 & $2 Z 5 J$ & 3.40 \\
\hline TNPO3 & Transportin-3 & 923 & $4 \mathrm{COO}$ & 2.56 \\
\hline XPO1 & Exportin-1 & 1044 & 5DIS & 2.85 \\
\hline XPO5 & Exportin-5 & 1204 & $3 \mathrm{~A} 6 \mathrm{P}$ & 2.92 \\
\hline
\end{tabular}

\section{Electrostatic potential analysis}

To investigate the surface properties of the proteins, prepared proteins were uploaded to the eF-surf PDBj (https://pdbj.org/eF-surf/top.do) web server. This server calculates the Electrostatic potential (ESP) and hydrophobic properties of the protein surface.

\section{Molecular docking}

\section{Protein-protein docking}

To investigate the protein-protein binding affinity and complex formation, molecular docking was performed at the widely used ClusPro 2.0 (https://cluspro.org) web server (Kozakov et al., 2017). ClusPro involves three important steps to dock protein structures, (a) rigid-body docking of Fast fourier transform (FFT) based generated billions of protein conformers using PIPER algorithm (b) Root mean square deviation (RMSD) based clustering of 1,000 complexes, and (c) refinement and energy minimization of complexes using CHARMM force field (Brooks et al., 1983) to remove steric clashes between the interacting protein interfaces. To perform the molecular docking, two proteins were uploaded to the server as receptor and ligand based on sequence length.

Initially, each protein was docked with itself to form homodimeric complexes and then docked with each other to get heterodimeric complexes. Hence, 12 homodimers and 66 heterodimers were obtained for further analysis. ClusPro gives best 30 complexes for each job after CHARMM energy minimization according to clustering probability and energy based (balanced, electrostatic-favored, hydrophobicfavored, and VDW+electrostatic-favored) parameters. In this study, best complexes were obtained by considering balanced energy parameter and higher clustering probability of complexes. The number of cluster members and the model cluster scores (cluster center and lowest energy) are shown in Supplementary Table 1. The cluster center weighted score indicates the structure in the cluster that has the highest number of neighbour structures while the lowest energy score designates the structure which has the lowest energy in the cluster. This model score can be calculated using following equation;

$E=0.40 E_{\text {rep }}+\left(-0.40 E_{\text {attr }}\right)+600 E_{\text {elec }}+1.00 E_{\text {DARS }}$

Where $E_{\text {rep }}$ and $E_{\text {attr }}$ indicate the repulsive and attractive terms of the van der Waals energy respectively whereas $E_{\text {elec }}$ denotes electrostatic energy term. $E_{D A R S}$ is pairwise structure-based potential obtained by the decoys as the reference state approach (Chuang et al., 2008) and represents the desolvation energy contribution.

These retrieved complexes were further analyzed for protein-protein interactions and binding energy. 


\section{Protein-protein interface interactions analysis}

To investigate the protein-protein interface interactions, PIMA (Mathew \& Sowdhamini, 2016) available at http://caps.ncbs.res.in/pima/ and PRODIGY (Xue et al., 2016) (https://wenmr.science.uu.nl/prodigy/) web servers were employed. PIMA calculates various energy terms (electrostatic energy, VDW energy, and total stabilization energy) in $\mathrm{kJ} / \mathrm{mol}$ and number of interactions (hydrogen bonds, VDW pairs, and salt bridges) along with number of interacting residues on the protein-protein interface whereas, PRODIGY gives binding energy $(\mathrm{kcal} / \mathrm{mol})$ of protein-protein complex. Furthermore, to validate the binding energy of docked complexes, experimentally solved eight protein-protein complexes were submitted to both the server for binding energy calculations. In the PIMA results, for the van der Waals energy, cutoff distance between protein atoms is $7 \AA$ and the magnitude can be derived from the following equation,

$V=4.184 \times \sqrt{E_{i} \times E_{j}}\left[\left(\frac{R_{i}+R_{j}}{r}\right)^{12}-2\left(\frac{R_{i}+R_{j}}{r}\right)^{6}\right]$

In the above equation, $R_{i}$ and $R_{j}$ are designated for the van der Waals radii of atom $i$ and $j$ whilst $E$ represents the van der Waals well depth. The distance between two atoms is indicated by $r$.

In the electrostatic energy ( $V$ ) calculation, cutoff distance was set to $10 \AA$ and energy can be calculated using following formula,

$V=4.184\left[\frac{q_{1} \times q_{2}}{D \times r}\right] 332$

Where, $q_{1}$ and $q_{2}$ are partial charges of atom $i$ and $j$ while $r$ is the distance between interacting two atoms.

The binding energy evaluated at the PRODIGY server, was calculated using following equation (Vangone \& Bonvin, 2015),

$$
\begin{aligned}
\Delta G_{\text {calc }}= & 0.09459 I C S_{\text {charged } / \text { charged }}+0.10007 I C S_{\text {charged } / \text { apolar }}- \\
& 0.19577 \text { IC } S_{\text {polar } / \text { polar }}+0.22671 \text { IC } s_{\text {polar } / \text { apolar }}- \\
& 0.18681 \% \text { NIS } S_{\text {apolar }}-0.13810 \% \text { NIS } S_{\text {charged }}+15.9433
\end{aligned}
$$

Where, ICs (Inter-residue contacts) and NIS (Non-interacting surface) terms indicate the contribution of various types of residues to the overall binding affinity.

\section{Results and discussion}

\section{Electrostatic potential analysis}

Electrostatic interactions are considered to be an important driving force in various biomolecular mechanisms and protein-ligand or protein-protein binding. Additionally, they also play crucial role in molecular recognition events (Hildebrandt et al., 2007). Furthermore, for proper folding of nascent proteins and their stability, as well as in enzyme catalytic reactions, electrostatic forces play pivotal role (Vascon et al., 2020). Figure 2 represents the electrostatic potential surface of each transport protein.

In this study, to understand how the transport proteins come together to find the suitable location for binding with their partners, surface of each protein was analyzed for electrostatic properties. It can be seen from the Figure 2 that in each protein, the internal surface of tandem repeats contains dominantly negative potential (red surface) whereas the outer surface has the significant amount of hydrophobic (white) residues. However, the amino acids which contribute to the positive potential (white) are distributed unevenly on the outer surface of the protein. 


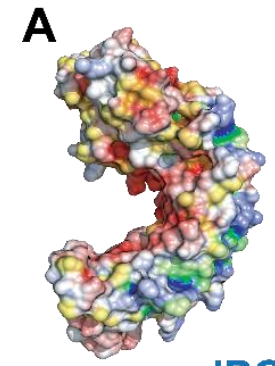

IPO4

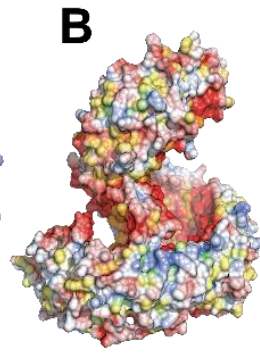

IPO5

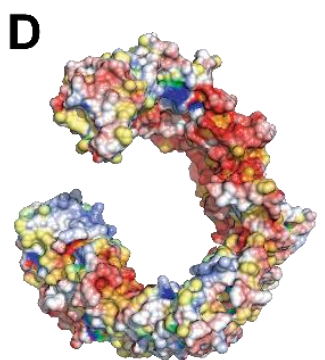

IP013

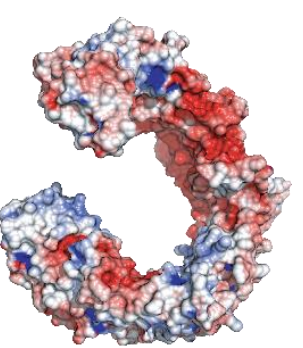

H

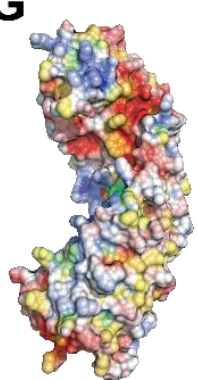

KPNA6

$\mathbf{J}$

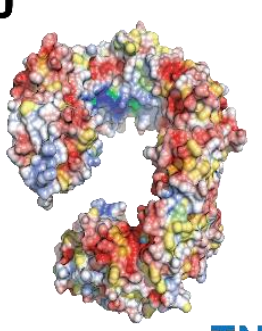

TNPO3
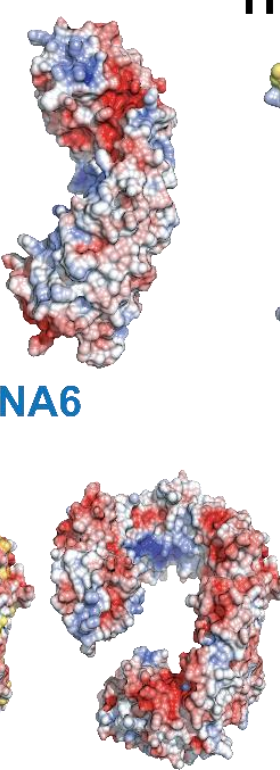
3

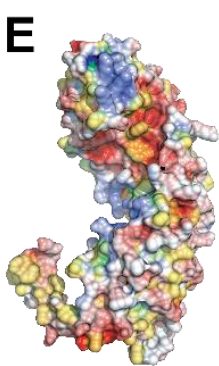

KPNA1

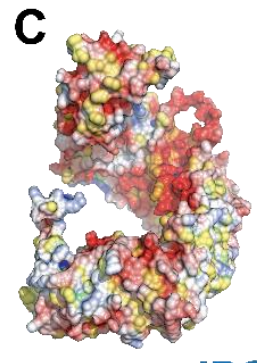

IPO9

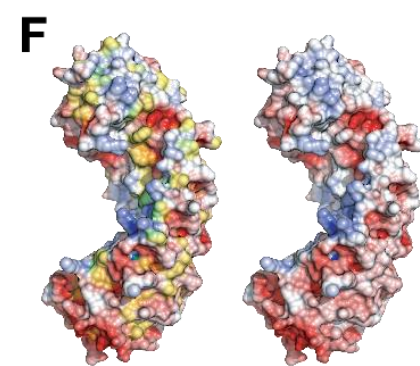

KPNA4
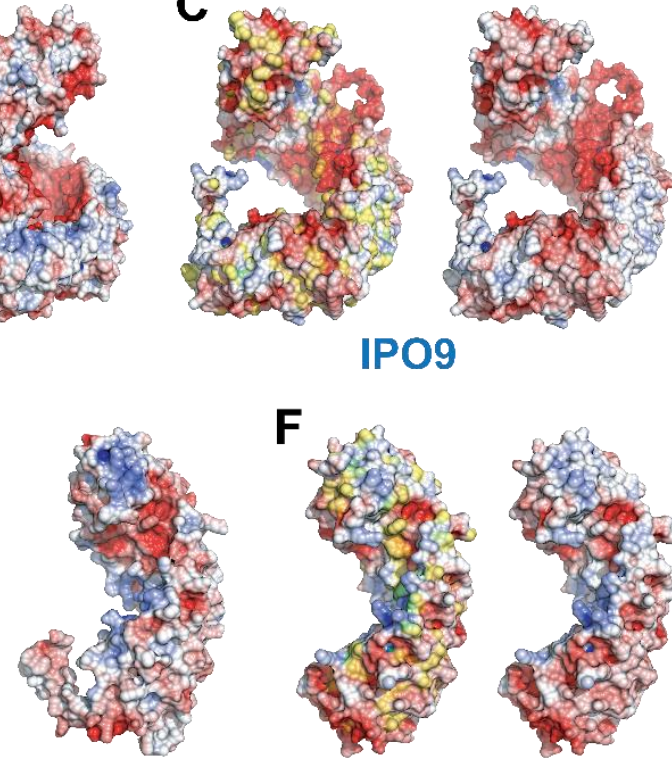

(1)

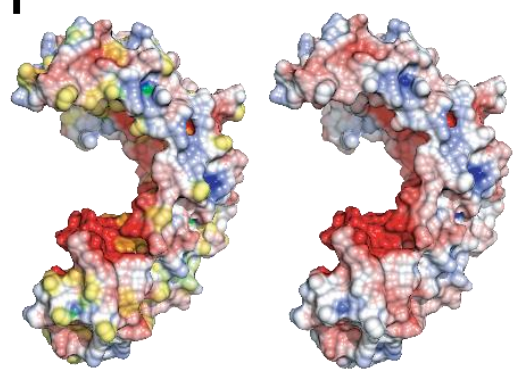

KPNB1

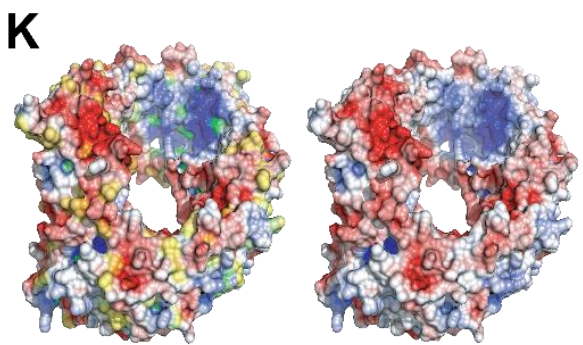

XPO1
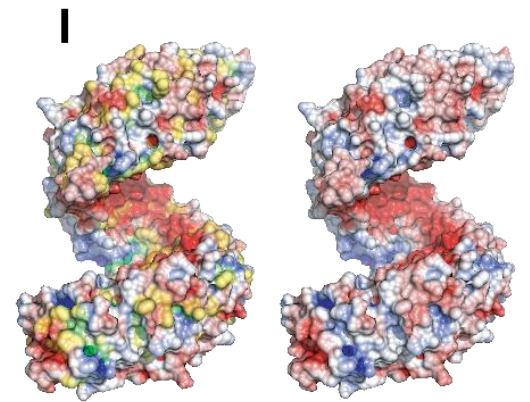

TNPO1

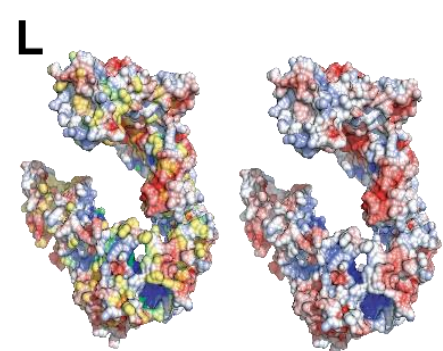

XPO5

Electrostatic potential

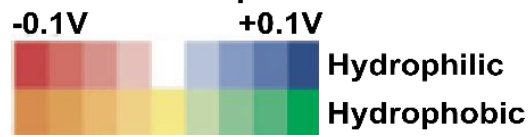

Figure 2. Hydrophobic and electrostatic (hydrophilic) potential surface representation of 12 human nuclear transport proteins.

\section{Molecular docking}

\section{Protein-protein docking}

Protein-protein docking is used in various biomolecular applications such as, exploration of enzyme conformations (Valdés et al., 2010), prediction of Interactomes (Kastritis \& Bonvin, 2011), molecular recognition (Mottin et al., 2015), protein dimerization (Qiao et al., 2019), design of specific probes for protein targets (Soulier et al., 2005), amyloid aggregation (Koldsø et al., 2015), predicting protein binding mechanisms (Kahler et al., 2020), peptide designing against diseases (Cui et al., 2010), vaccine designing (Z. Yang et al., 2021). In this study, binding energies and types of interactions of 
docked transport protein complexes (12 homodimers and 66 heterodimers) were evaluated using various computational tools. The calculated binding energy of complexes by PIMA and PRODIGY web servers are shown in Table 2 and complex structures are illustrated in Figure 3.

IPO4

IPO4 or importin-4 comes under importin- $\beta$ family. It transports the cargo by forming complex with importin- $\alpha$ which recognises the Nuclear localization signal (NLS) of cargo proteins. Inside the nucleus, this complex (importin- $\alpha$ :importin- $\beta$ :cargo) interacts with the RanGTP and releases the cargo into the nucleus. IPO4 transports the histone $\mathrm{H} 3$ and $\mathrm{H} 4$ cargo proteins into the nucleus. It plays vital role in gastric cancer (Xu et al., 2019). It has been reported that inhibition of IPO4 increases the chemosensitivity in cervical cancer (Zhou et al., 2020). Figure 1A shows the structure of IPO4.

The IPO4 was docked with itself to form a homodimer and with 11 other transport proteins (IPO5, IPO9, IPO13, KPNA1, KPNA4, PPNA6, KPNB1, TNPO1, TNPO3, XPO1, and XPO5) to form a heterodimeric protein complexes (Figure 3A). In homodimer (IPO4-IPO4), structural investigation indicates that the C-terminal regions interact with each other and form a complex. Three helices at the C-terminal region interact to form hydrogen bonds and van der Waals bonds within the homodimer. From the results (Supplementary Table 2), it was observed that the van der Waals interactions contribute extensively higher over electrostatic interactions in homodimer. However, from the binding energy values (Table 2), among 11 heterodimeric protein complexes, IPO4 strongly binds with IPO5 and IPO9 (IPO4-IPO5: -677.4 kJ/mol; IPO4-IPO9: -690.1 kJ/mol) compared to other proteins. In other complexes, van der Waals and electrostatic energy contribution differ from one complex to another. Complexes are shown in Figure 3A.

\section{IPO5}

In humans, IPO5 gene encodes IPO5 protein (Deane et al., 1997). Like IPO4, it is also a member of importin- $\beta$ family. It forms a structure like right hand solenoid (Figure 1B) and has 24 HEAT (Huntingtin, Elongation factor 3 (EF3) 1, Protein phosphatase 2A (PP2A) 2, and the yeast Phosphoinositide 3-kinase (PI3K) Target of rapamycin 1 (TOR1)) repeats (Swale et al., 2020). It imports CPEB3 (Cytoplasmic polyadenylation element-binding protein 3 ) into the nucleus through NMDAR (N-methyl-D-aspartate receptor) signaling and RanGTP driving processes (Chao et al., 2012). The transcription factor, Interferon regulatory factor 3 (IRF3) is transported to the nucleus with the help of IPO5 (D. Li et al., 2019). Study also suggested that IPO5 directly interacts with receptor known as DSCAM (Down syndrome cell adhesion molecule) which is responsible for neural development processes (Sachse et al., 2019). Another finding reports that SMAD1 (Suppressor of mothers against decapentaplegic 1) binding with IPO5 is involved in the cell development and growth (Baas et al., 2016). Additionally, IPO5 is involved in cancer (X. F. Li et al., 2020; W. Zhang et al., 2019) and viral protein transport (Deng et al., 2006).

Total 11 complexes (1 homodimer and 10 heterodimers) of IPO5 with IPO5, IPO9, IPO13, KPNA1, KPNA4, PPNA6, KPNB1, TNPO1, TNPO3, XPO1, and XPO5 were obtained (Figure 3B) to evaluate their binding affinities and study their interactions at the interfaces. It was observed that the $\mathrm{N}$ - and $\mathrm{C}$ terminal regions interact dominantly. From the binding energy values calculated at PIMA server, among all the heterodimeric protein complexes, IPO5-KPNB1 has the highest stability (binding energy: -456.9 $\mathrm{kJ} / \mathrm{mol}$ ). However, the PRODIGY server predicts IPO5-KPNA1, IPO5-TNPO3, and IPO5-XPO5 as having highest stability (binding energy $>-60 \mathrm{~kJ} / \mathrm{mol}$ ) among all the complexes. Further, results indicate that van der Waals energy is contributing more in comparison with electrostatic energy to the total stabilization energy for all the complexes except IPO5-KPNB1 (electrostatic energy: - $235.4 \mathrm{~kJ} / \mathrm{mol}$, van der Waals energy: $-221.5 \mathrm{~kJ} / \mathrm{mol}$ ). The binding modes of receptor and ligand differ significantly in all the 11 complexes.

\section{IPO9}

Importin-9 is encoded by IPO9 gene (Jakel, 2002). IPO9 is composed of 20 tandem HEAT repeats and each repeat has two antiparallel helices. The concave surface of protein has mostly acidic residues (Padavannil et al., 2019). Study shows that importin-9 negatively regulates the expression of 
Table 2. Binding energy $(\mathrm{kJ} / \mathrm{mol})$ of 78 protein-protein complexes calculated using PIMA and PRODIGY web servers.

\begin{tabular}{|c|c|c|c|c|c|c|c|}
\hline \multirow[t]{2}{*}{$\begin{array}{l}\text { Complex } \\
\text { number }\end{array}$} & \multirow[t]{2}{*}{$\begin{array}{l}\text { Complex } \\
\text { name }\end{array}$} & \multicolumn{2}{|c|}{$\begin{array}{c}\text { Binding energy } \\
(\mathrm{kJ} / \mathrm{mol})\end{array}$} & \multirow[t]{2}{*}{$\begin{array}{l}\text { Complex } \\
\text { number }\end{array}$} & \multirow[t]{2}{*}{$\begin{array}{l}\text { Complex } \\
\text { name }\end{array}$} & \multicolumn{2}{|c|}{$\begin{array}{l}\text { Binding energy } \\
(\mathrm{kJ} / \mathrm{mol})\end{array}$} \\
\hline & & PIMA & PRODIGY & & & PIMA & PRODIGY \\
\hline \multicolumn{4}{|c|}{ IPO4 } & 42 & IP013-XPO5 & -695.6 & -92.0 \\
\hline 1 & IPO4-IPO4 & -187.9 & -34.3 & \multicolumn{4}{|c|}{ KPNA1 } \\
\hline 2 & IPO4-IPO5 & -677.4 & -63.2 & 43 & KPNA1-KPNA1 & -423.8 & -54.4 \\
\hline 3 & IPO4-IPO9 & -690.1 & -72.4 & 44 & KPNA1-KPNA4 & -390.0 & -58.2 \\
\hline 4 & IPO4-IPO13 & -427.3 & -65.3 & 45 & KPNA1-KPNA6 & -394.9 & -56.5 \\
\hline 5 & IPO4-KPNA1 & -242.6 & -49.4 & 46 & KPNA1-KPNB1 & -295.6 & -59.8 \\
\hline 6 & IPO4-KPNA4 & -148.6 & -49.4 & 47 & KPNA1-TNPO1 & -396.5 & -47.3 \\
\hline 7 & IPO4-KPNA6 & -322.5 & -41.4 & 48 & KPNA1-TNPO3 & -567.6 & -51.5 \\
\hline 8 & IPO4-KPNB1 & -304.6 & -53.1 & 49 & KPNA1-XPO1 & -269.4 & -48.5 \\
\hline 9 & IPO4-TNPO1 & -425.1 & -66.9 & 50 & KPNA1-XPO5 & -207.5 & -43.9 \\
\hline 10 & IPO4-TNPO3 & -353.6 & -69.0 & \multicolumn{4}{|c|}{ KPNA4 } \\
\hline 11 & IPO4-XPO1 & -437.9 & -56.5 & 51 & KPNA4-KPNA4 & -379.1 & -54.8 \\
\hline 12 & IPO4-XPO5 & -306.2 & -71.1 & 52 & KPNA4-KPNA6 & -241.3 & -61.9 \\
\hline \multicolumn{4}{|c|}{ IPO5 } & 53 & KPNA4-KPNB1 & -149.3 & -49.0 \\
\hline 13 & IPO5-IPO5 & -315.9 & -57.7 & 54 & KPNA4-TNPO1 & -320.8 & -63.2 \\
\hline 14 & IPO5-IPO9 & -289.5 & -46.9 & 55 & KPNA4-TNPO3 & -342.1 & -57.7 \\
\hline 15 & IPO5-IPO13 & -240.8 & -50.6 & 56 & KPNA4-XPO1 & -245.6 & -61.9 \\
\hline 16 & IPO5-KPNA1 & -422.9 & -61.5 & 57 & KPNA4-XPO5 & -490.6 & -61.5 \\
\hline 17 & IPO5-KPNA4 & -324.5 & -54.4 & \multicolumn{4}{|c|}{ KPNA6 } \\
\hline 18 & IPO5-KPNA6 & -237.5 & -47.3 & 58 & KPNA6-KPNA6 & -354.6 & -60.7 \\
\hline 19 & IPO5-KPNB1 & -456.9 & -53.1 & 59 & KPNA6-KPNB1 & -210.3 & -61.9 \\
\hline 20 & IPO5-TNPO1 & -335.1 & -48.5 & 60 & KPNA6-TNPO1 & -215.2 & -46.0 \\
\hline 21 & IPO5-TNPO3 & -350.4 & -63.2 & 61 & KPNA6-TNPO3 & -771.7 & -79.5 \\
\hline 22 & IPO5-XPO1 & -354.3 & -50.6 & 62 & KPNA6-XPO1 & -511.6 & -48.5 \\
\hline 23 & IPO5-XPO5 & -277.7 & -62.3 & 63 & KPNA6-XPO5 & -465.5 & -66.1 \\
\hline \multicolumn{4}{|c|}{ IPO9 } & \multicolumn{4}{|c|}{ KPNB1 } \\
\hline 24 & IP09-IPO9 & -398.4 & -62.8 & 64 & KPNB1-KPNB1 & -146.5 & -28.0 \\
\hline 25 & IP09-IPO13 & -696.2 & -61.5 & 65 & KPNB1-TNPO1 & -559.7 & -65.3 \\
\hline 26 & IPO9-KPNA1 & -254.4 & -54.8 & 66 & KPNB1-TNPO3 & -439.2 & -69.9 \\
\hline 27 & IPO9-KPNA4 & -339.7 & -56.5 & 67 & KPNB1-XPO1 & -406.3 & -66.9 \\
\hline 28 & IPO9-KPNA6 & -669.9 & -79.1 & 68 & KPNB1-XPO5 & -578.2 & -68.2 \\
\hline 29 & IPO9-KPNB1 & -369.0 & -44.8 & \multicolumn{4}{|c|}{ TNPO1 } \\
\hline 30 & IPO9-TNPO1 & -250.1 & -50.6 & 69 & TNPO1-TNPO1 & -576.6 & -63.2 \\
\hline 31 & IPO9-TNPO3 & -492.0 & -69.5 & 70 & TNPO1-TNPO3 & -400.4 & -72.8 \\
\hline 32 & IPO9-XPO1 & -221.8 & -49.4 & 71 & TNPO1-XPO1 & -287.4 & -57.3 \\
\hline 33 & IP09-ХPO5 & 1466.3 & -70.3 & 72 & TNPO1-XPO5 & -543.0 & -66.1 \\
\hline \multicolumn{4}{|c|}{ IP013 } & \multicolumn{4}{|c|}{ TNPO3 } \\
\hline 34 & IP013-IP013 & -780.9 & -74.9 & 73 & TNPO3-TNPO3 & -250.9 & -50.6 \\
\hline 35 & IP013-KPNA1 & 1929.2 & -69.9 & 74 & TNPO3-XPO1 & -449.9 & -66.5 \\
\hline 36 & IP013-KPNA4 & -377.6 & -50.2 & 75 & TNPO3-XPO5 & -469.6 & -77.8 \\
\hline 37 & IPO13-KPNA6 & -655.0 & -67.8 & \multicolumn{4}{|c|}{ XP01 } \\
\hline 38 & IP013-KPNB1 & -557.9 & -75.7 & 76 & XPO1-XPO1 & -334.5 & -58.2 \\
\hline 39 & IP013-TNPO1 & -453.4 & -69.5 & 77 & ХPO1-ХРO5 & -514.2 & -54.4 \\
\hline 40 & IPO13-TNPO3 & -360.7 & -59.4 & \multicolumn{4}{|c|}{ XPO5 } \\
\hline 41 & IP013-XPO1 & -586.5 & -80.8 & 78 & ХРО5-ХРO5 & -391.8 & -54.4 \\
\hline
\end{tabular}

Interferon $\varepsilon$ (IFN- $\varepsilon$ ) (Matsumiya et al., 2013). Another finding revealed that the actin import into the nucleus is facilitated by IPO9 (Dopie et al., 2012). It also helps to import Aristaless related homeobox (ARX) protein (Lin et al., 2009). The structure of IPO9 is presented in the Figure 1C.

To investigate the complex formation tendency of IPO9, it was docked with 10 transport proteins (IPO9, IPO13, KPNA1. KPNA4, KPNA6, TNPO1, TNPO3, XPO1, and XPO5). PIMA and PRODIGY predict 
bioRxiv preprint doi: https://doi.org/10.1101/2021.03.22.436462; this version posted March 22, 2021. The copyright holder for this preprint (which was not certified by peer review) is the author/funder, who has granted bioRxiv a license to display the preprint in perpetuity. It is made available under aCC-BY-NC-ND 4.0 International license.

different complexes to be stable. IPO9-IPO13 (binding energy: $-686.2 \mathrm{~kJ} / \mathrm{mol}$ ) and IPO9-KPNA6 (binding energy: $-669.9 \mathrm{~kJ} / \mathrm{mol}$ ) have the higher binding energies in comparison with other complexes in PIMA prediction however, PRODIGY binding energy data suggests that IPO9-KPNA6 (binding energy: $-79.1 \mathrm{~kJ} / \mathrm{mol}$ ) and IPO9-XPO5 (binding energy: $-70.3 \mathrm{~kJ} / \mathrm{mol}$ ) are highly stable. In all the complexes, at the protein-protein interfaces, the strength of binding is mainly attributed to the van der Waals forces whereas coulomb forces contribute less (Supplementary Table 2). Additionally, it was observed that IPO9 forms 24, 17, and 14 salt bridges with IPO13, KPNA6, and XPO5 respectively and six hydrogen bonds with these three proteins thus, these complexes have the highest contribution to the total stabilization energy comes from electrostatic forces compared to the other complexes. In case of IPO9-XPO5, PIMA predicts the highest stabilization energy with positive sign and this is due to more number of van der Waals pair formation at the interface. But, the positive sign indicates a close proximity of atoms. Considering the binding modes, some ligands bind to the concave and convex patches of IPO9 whereas some bind at the N- and C-terminal regions of the IPO9. All the complexes of IPO9 are illustrated in Figure $3 \mathrm{C}$.

\section{IP013}

IPO13 gene encodes Importin-13 or IPO13 (Mingot et al., 2001). Researchers unexpectedly found that IPO13 also serves to export elF1A (Eukaryotic translation initiation factor 1A) (Baade et al., 2018). It acquires highly flexible as well as fairly tight conformations to bind and assist different cargo transports. From the experimentally solved crystal structures, it was noted that IPO13 identifies distinct cargos through different interaction modes (Bono et al., 2010; Grünwald et al., 2013; Grünwald \& Bono, 2011). Further study shows that IPO13 plays a major role in the regulation of embryonic stem cell differentiation and pluripotency (Fatima et al., 2021). Moreover, it transports various cargos such as, chromatin-histone assembly complex (Walker et al., 2009), heterotrimeric transcription factor NF-Y (Nuclear factor Y) (Kahle et al., 2005), and myopodin (Liang et al., 2008). The crystal structure of IPO13 is given in Figure 1D.

There were nine protein-protein complexes of IPO13 including a IPO13 (homodimer) and heterodimers with KPNA1, KPNA4, KPNA6, KPNB1, TNPO1, TNPO3, XPO1, and XPO5 obtained. PIMA results show that IPO13-IPO13 complex has the highest interface interaction energy $-780.9 \mathrm{~kJ} / \mathrm{mol}$, whereas IPO13XPO5 is predicted highly stable (binding energy: $-92.0 \mathrm{~kJ} / \mathrm{mol}$ ) by PRODIGY. In these complexes, IPO13 forms approximately same number of salt bridges ( 30) but have significant change in the number of hydrogen bonds and van der Waals pairs (IPO13-IPO13: 5693 and IPO13-XPO5: 7102). Additionally, IPO13-KPNA6, IPO13-KPNB1, and IPO13-XPO1 have greater than $-550 \mathrm{~kJ} / \mathrm{mol}$ energy which indicates that IPO13 forms stable complexes with KPNA6, KPNB1, and XPO1. Out of ten complexes, in five complexes, binding was observed at the $\mathrm{N}$ - and $\mathrm{C}$-terminals of IPO13 whereas in other, it was observed at different regions. Alike IPO9-XPO5 complex, IPO13-KPNA1 complex has also atoms closely packed which results into higher van der Waals energy with positive sign. Figure 3D represents the structures of IPO13 complexes.

\section{KPNA1}

Importin subunit $\alpha-1$ or karyopherin $\alpha-1$ is encoded by KPNA1 gene (Cortes, 1994). It was reported that KPNA1 interacts with Karyopherin subunit $\beta-1$ (KPNB1) (Percipalle et al., 1997) and Ubiquitin protein ligase E3 component N-recognin 5 (UBR5) (Henderson et al., 2002). Study showed that KPNA1 binds with Signal transducer and activator of transcription (STAT) protein dimer and mediates the transport during cell signaling (Fagerlund et al., 2002). The structure of KPNA1 is illustrated in Figure 1E.

KPNA1 was docked with KPNA1, KPNA4, KPNA6, KPNB1, TNPO1, TNPO3, XPO1, and XPO5 (Figure $3 E$ ). PIMA and PRODIGY both predicted homodimeric complex structure being highly stable (PIMA binding energy: $-423.8 \mathrm{~kJ} / \mathrm{mol}$, PRODIGY binding energy: $-54.4 \mathrm{~kJ} / \mathrm{mol}$ ). In heterodimeric complexes, PIMA results indicate that KPNA1 binds tightly to the TNPO3 (Binding energy: $-567.6 \mathrm{~kJ} / \mathrm{mol}$ ) while PRODIGY gives average binding energy $-55 \mathrm{~kJ} / \mathrm{mol}$ for KPNA1-KPNA4, KPNA1-KPNA6, and KPNA1KPNB1 complexes which shows stable complex formation and remainder have binding energy more than $-40 \mathrm{~kJ} / \mathrm{mol}$ which indicates their partial stability. The number of hydrogen bond in the homodimer are significantly higher ( 20) compared to reminder heterodimeric complexes. KPNA1 forms 29 salt bridges with TNPO3 hence, the stability of this complex is mainly attributed to the electrostatic 
interactions (electrostatic energy: $-313.7 \mathrm{~kJ} / \mathrm{mol}$ ) which are dominant over van der Waals interactions (van der Waals energy: $-253.9 \mathrm{~kJ} / \mathrm{mol}$ ).

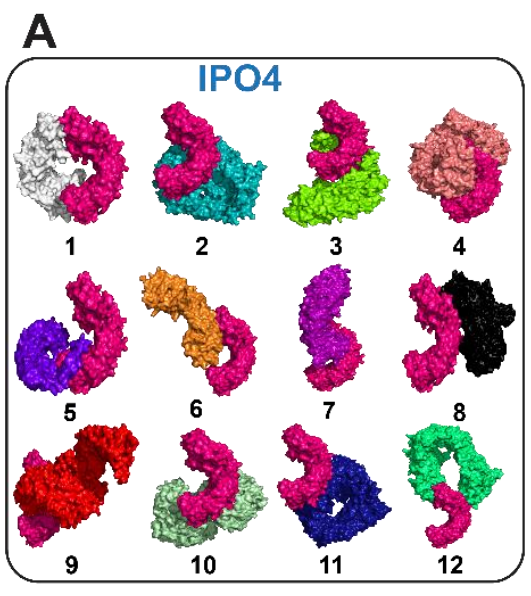

B
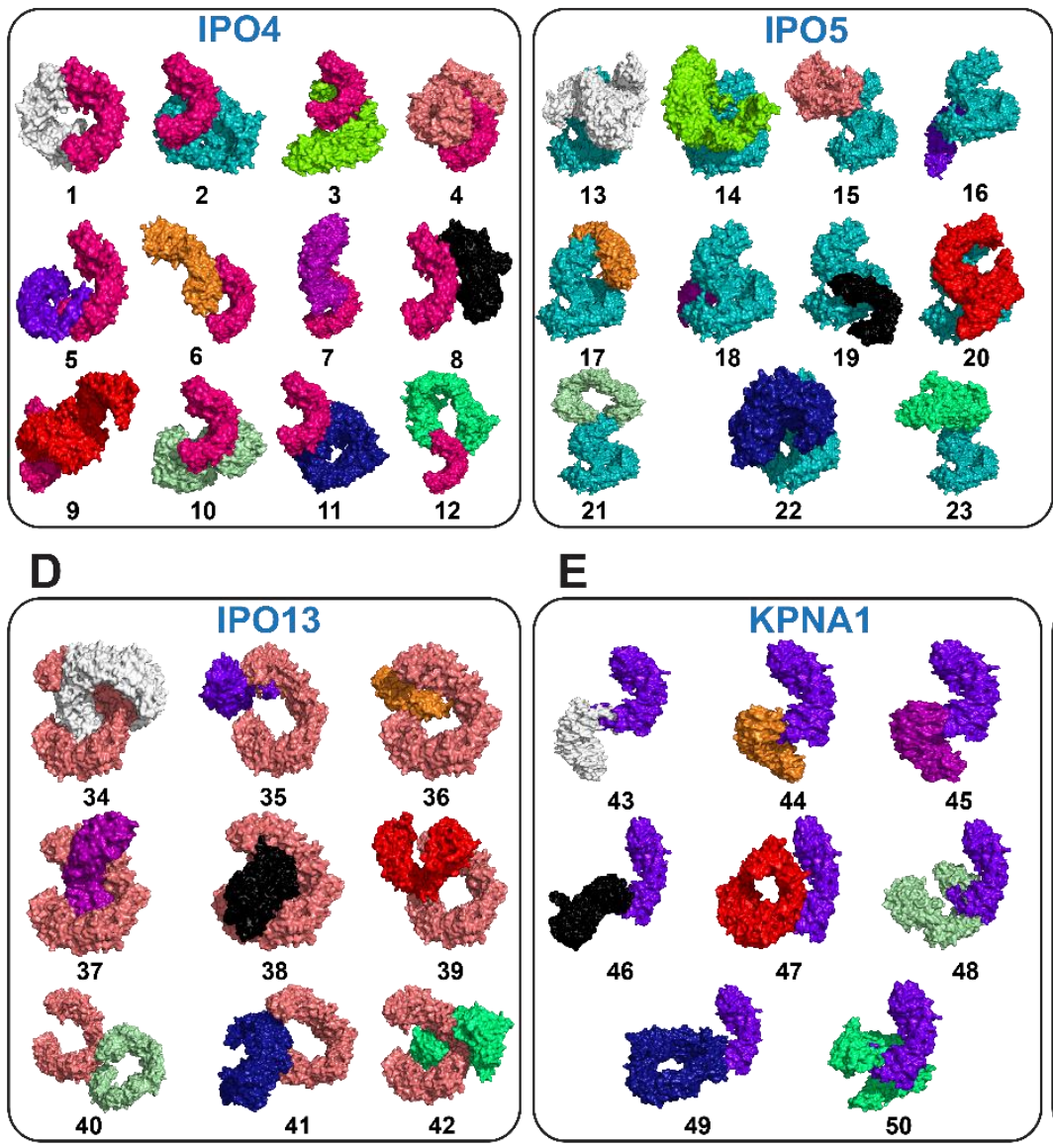

E
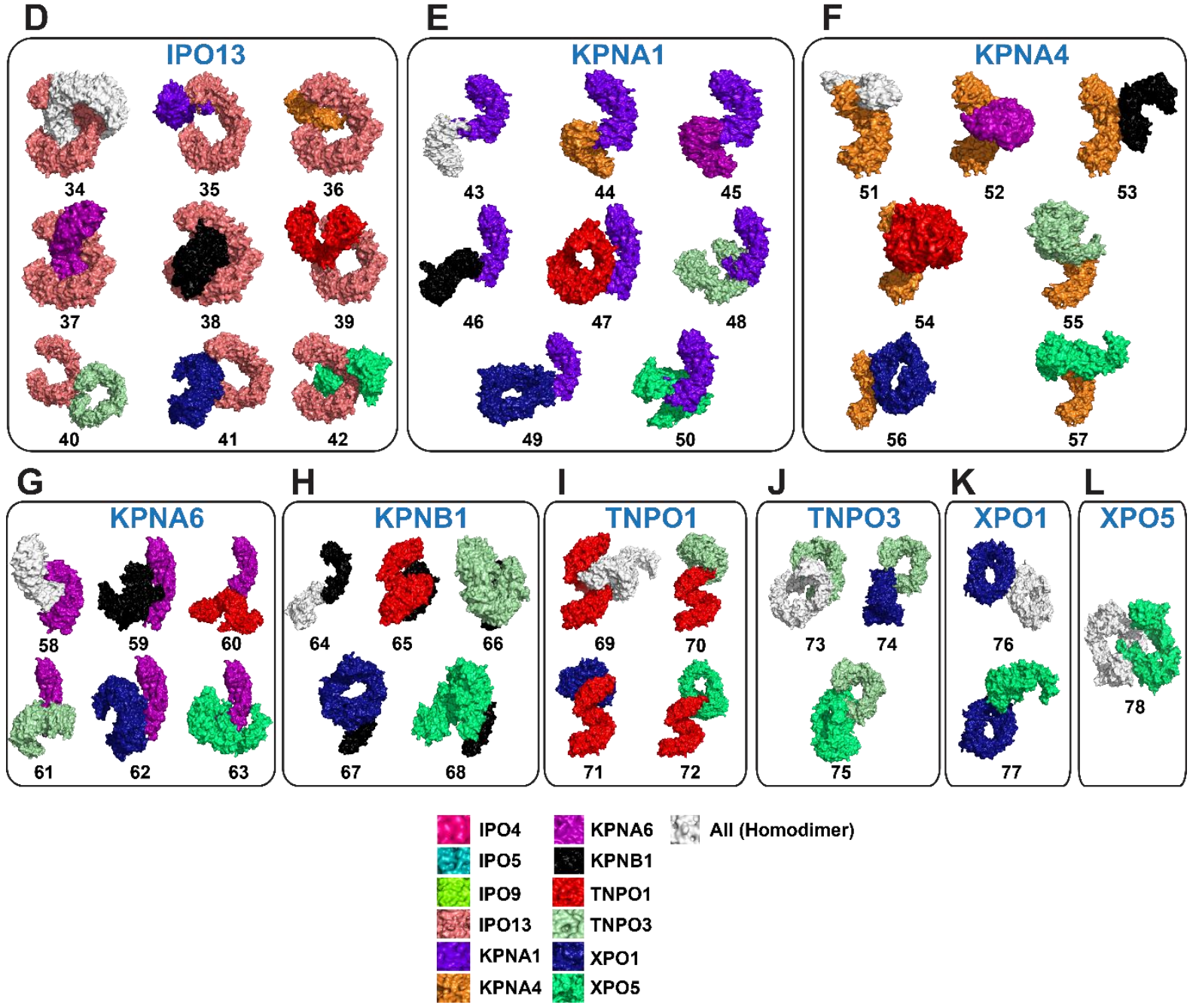

Figure 3. Docked 78 complexes (12 homodimers and 66 heterodimers) of 12 human nuclear transport proteins. The specific color is given to each protein in the complexes but in case of homodimer, the monomer is illustrated in white.

\section{KPNA4}

Karyopherin subunit $\alpha-4$ or Importin $\alpha-3$ (IPOA3) protein which is encoded by KPNA4 gene in humans (Köhler et al., 1997; Seki et al., 1997). Research shows that KPNA4 interacts with ATP-dependent DNA helicase Q1 also known as RECQL (Seki et al., 1997) and, Signal transducer and activator of 
transcription 3 (STAT3) protein (Liu et al., 2005). Literature suggested that KPNA4 is involved in many biomolecular processes which leads to various cancers (Hu et al., 2020; J. Yang et al., 2017; M. Zhang et al., 2019). The crystal structure of KPNA4 is shown in Figure 1F.

KPNA4 was first docked with itself to form homodimer and then with six proteins (KPNA6, KPNB1, TNPO1, TNPO3, XPO1, and XPO5) to form heterodimers. PIMA binding energy analysis shows that KPNA4 has the highest binding affinity for the XPO5 (binding energy: $-490.6 \mathrm{~kJ} / \mathrm{mol}$ ) in comparison with other remaining proteins. However, PRODIGY results predict KPNA4-TNPO1 highly stable among all the complexes. Additionally, KPNA4-KPNA6, KPNA4-XPO1, and KPNA4-XPO5 have average PRODIGY binding energy of $-61.5 \mathrm{~kJ} / \mathrm{mol}$ which shows stable complex formation. It was noted that most of the proteins interact with $\mathrm{N}$-terminal and concave region of KPNA4 (Figure 3F). In all the complexes, van der Waals interactions contribute significantly to the binding energy compared to electrostatic interactions but, it was observed that KPNA4 forms 26 salt bridges with XPO5 and consequently, these interactions (electrostatic energy: $-236.5 \mathrm{~kJ} / \mathrm{mol}$ ) also play a major role in complex formation. All the complexes of KPNA4 are shown in Figure 3F.

\section{KPNA6}

KPNA6 or Importin subunit $\alpha-7$ (IPOA7) is encoded by KPNA6 gene (Köhler et al., 1999). KPNA6 binds to the kelch domain of Kelch-like ECH-associated protein 1 (KEAP1) and regulates the Nuclear factor erythroid 2-related factor 2 (NRF2) signaling (Sun et al., 2011). Figure 1G represents the structure of KPNA6.

KPNA6 was docked with KPNA6, KPNB1, TNPO1, TNPO3, XPO1, and XPO5. PIMA and PRODIGY both predict KPNA6-TNPO3 complex to be highly stable based on binding energy (PIMA binding energy: $-771.7 \mathrm{~kJ} / \mathrm{mol}$, PRODIGY binding energy: $-79.5 \mathrm{~kJ} / \mathrm{mol}$ ). The binding energy of KPNA6-KPNA6 homodimer is $-354.6 \mathrm{~kJ} / \mathrm{mol}$ and $-60.7 \mathrm{~kJ} / \mathrm{mol}$ calculated using PIMA and PRODIGY respectively. Among the KPNA6-XPO1 and KPNA6-XPO5 complexes, KPNA6 has stronger affinity for XPO1 (binding energy: $-511.6 \mathrm{~kJ} / \mathrm{mol}$ ) than XPO5 (binding energy: $-465.5 \mathrm{~kJ} / \mathrm{mol}$ ) binding. KPNA6 forms 30,22 , and 19 salt brides with TNPO3, XPO5, and XPO1 respectively hence, in these complexes (KPNA6-TNPO3, KPNA6-XPO1, and KPNA6-XPO5), electrostatic interactions contribute significantly to the overall stabilization energy. Most of the proteins bind at the C-terminal region of the KPNA6 except in the homodimer where the other monomer interacts with the $\mathrm{N}$-terminal and convex regions. These complexes are illustrated in the Figure 3G.

\section{KPNB1}

KPNB1 gene encodes Importin subunit $\beta-1$ or KPNB1 protein (Chi et al., 1995). It plays pivotal role in mitotic events during cell cycle (Zhu et al., 2018). It is also involved in various cancers and thus many inhibitors have been developed for KPNB1 to fight against cancer (Du et al., 2020; Yong Hak Kim et al., 2016; Kodama et al., 2017; Sekimoto et al., 2017; T. Wang et al., 2019; Jian Yang et al., 2019). Figure $1 \mathrm{H}$ represents the crystal structure of KPNB1. The binding energy of docked complexes calculated at the PIMA and PRODIGY web servers is graphically represented in Figure 4.

KPNB1 was docked with itself and also four other proteins (TNPO1, TNPO3, XPO1, and XPO5). Binding energy of complexes calculated using PIMA shows that it binds tightly with TNPO1 (binding energy: $559.7 \mathrm{~kJ} / \mathrm{mol}$ ) and XPO5 (binding energy: $-578.2 \mathrm{~kJ} / \mathrm{mol}$ ). Interface interactions between monomers in homodimer are found less and they form a weak complex. PRODIGY binding energy for all the complexes was found approximately $-65 \mathrm{~kJ} / \mathrm{mol}$ except the homodimeric complex (binding energy: $28.0 \mathrm{~kJ} / \mathrm{mol}$ ). In all of the complexes, van der Waals interactions contribute considerably high compared to coulomb interactions. Each protein binds to KPNB1 at the central region. The protein-protein complexes of KPNB1 are illustrated in Figure $3 \mathrm{H}$. 


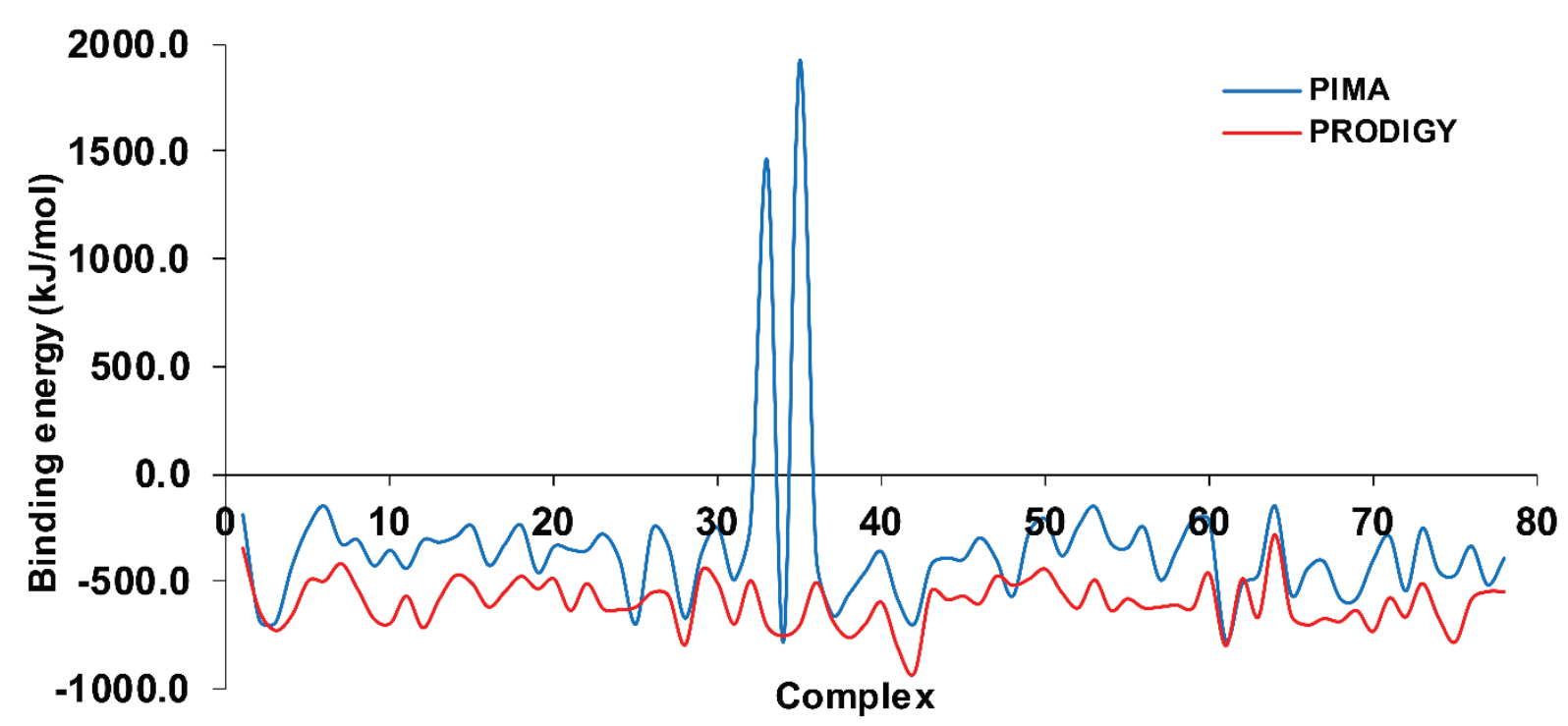

Figure 4. Graphical representation of binding energy $(\mathrm{kJ} / \mathrm{mol})$ of 78 complexes calculated using PIMA and PRODIGY web servers. PRODIGY results were converted into $\mathrm{kJ} / \mathrm{mol}$ and multiplied by ten to view the exact trend and difference in binding energy calculated at PIMA and PRODIGY for each complex.

\section{TNP01}

Transportin-1 (TNPO1) is also known as Importin $\beta-2$ is encoded by TNPO1 gene in humans (Bonifaci et al., 1997; Pollard et al., 1996). TNPO1 does not need importin- $\alpha$ subunit during cargo transport (Fridell et al., 1997). In addition, TNPO1 also helps to protein transports into the primary cilium (Hurd et al., 2011). It also transports ribosomal proteins into the cells (Ström \& Weis, 2001). Another study showed that TNPO1 is implicated in two neurodegenerative diseases, Amyotrophic lateral sclerosis (ALS) and Frontotemporal dementia (FTD) (Brelstaff et al., 2011). The crystal structure of TNPO1 is shown in Figure 11.

TNPO1 was first docked with its protomer and then with TNPO3, XPO1, and XPO5. The magnitudes of binding energy evaluated at the PIMA server show that homodimer has the highest stability (binding energy: $-576.6 \mathrm{~kJ} / \mathrm{mol}$ ) compared to heterodimeric complexes whereas PRODIGY predicts TNPO1TNPO3 complex to be highly stable. In addition, TNPO1 also binds tightly with XPO5 and forms stable complex (PIMA binding energy: $-543.0 \mathrm{~kJ} / \mathrm{mol}$, PRODIGY binding energy: $-66.1 \mathrm{~kJ} / \mathrm{mol}$ ). There are 14 hydrogen bonds observed between the TNPO1 and TNPO3 protein interfaces while 22 and 16 salt bridges are formed in TNPO1-TNPO1 and TNPO1-XPO5 complexes respectively. Though the van der Waals forces are dominantly contributing to the total stabilization energy, due to the more number of hydrogen bonds and salt bridges, electrostatic forces also contribute significantly. In all the complexes except homodimer (TNPO1-TNPO1), proteins interact at the C-terminal region of TNPO1 receptor. Protein complexes are illustrated in Figure 3l.

\section{TNPO3}

TNPO3 protein is encoded by TNPO3 gene (Kataoka et al., 1999). TNPO3 also known as transportinSR2 is a carrier and the transporter of splicing factor in humans (Maertens et al., 2014). Literature study suggests that TNPO3 mediates virus entry and particularly it is involved in Human immunodeficiency virus (HIV) (Bochnakian et al., 2019; De laco et al., 2013; Rice et al., 2020; ValleCasuso et al., 2012). Additionally, clinical study suggests that it plays a role in primary biliary cirrhosis and systemic sclerosis (Radstake et al., 2010). Structure of TNPO3 is illustrated in Figure 1J.

TNPO3 was docked with itself and other proteins, XPO1 and XPO5. PIMA and PRODIGY both servers predict that TNPO3 forms stable complex with XPO1 (PIMA binding energy: $-449.9 \mathrm{~kJ} / \mathrm{mol}$, PRODIGY binding energy: $-469.6 \mathrm{~kJ} / \mathrm{mol}$ ) and XPO5 (PIMA binding energy: $-66.5 \mathrm{~kJ} / \mathrm{mol}$, PRODIGY binding energy: $-77.8 \mathrm{~kJ} / \mathrm{mol}$ ). In the homodimer, monomers interact poorly and form a weak complex compared to heterodimeric complexes. The van der Waals interactions were observed at the protein-protein 
interfaces and they were found to high in number compared to electrostatic interactions (hydrogen bond and salt bridge). In the homodimer, electrostatic energy was found $15.7 \mathrm{~kJ} / \mathrm{mol}$ thus, positive energy indicates some atoms repel each other at the interacting interface. Proteins in all three complexes interact at the C- and N-terminal locations of the TNPO3 (Figure 3J).

\section{XPO1}

Chromosomal region maintenance 1 (CRM1) is the other name of Exportin-1 (XPO1) which is encoded by XPO1 gene (Miloudi et al., 2020). It has 24 HEAT repeats which form ring like structure and the hydrophobic pocket recognizes the Nuclear localization signal (NES) to transport various cargos (Dong et al., 2009). Literature studies show that XPO1 transports various RNA species such as snRNAs, mRNAs, tRNAs, rRNAs, and microRNAs (Hutten \& Kehlenbach, 2007). It transports approximately 220 proteins (Fu et al., 2013). Like other transport proteins, it is also involved in the various cancers and plays a critical role (Aladhraei et al., 2019; Camus et al., 2017; David et al., 2019; J. Kim et al., 2016). Figure $1 \mathrm{~K}$ illustrates the structure of XPO1.

Exportin-1 was docked with its monomer and another protein Exportin-5 (XPO5). PIMA binding energy values predict heterodimeric complex (XPO1-XPO5) to be more stable (binding energy: $-514.2 \mathrm{~kJ} / \mathrm{mol}$ ) compared to homodimer (binding energy: $-334.5 \mathrm{~kJ} / \mathrm{mol}$ ). However, though no significant difference was observed in the binding energies of homodimer and heterodimer, PRODIGY predicts homodimer to be more stable (homodimer binding energy: $-58.2 \mathrm{~kJ} / \mathrm{mol}$, heterodimer binding energy: $-54.4 \mathrm{~kJ} / \mathrm{mol}$ ). Further analysis suggests that there are 19 salt bridges present at the interfaces of XPO1 and XPO5 which indicates that electrostatic interactions contribute significantly to the total stabilization energy of XPO1-XPO5 complex. In both the complexes, XPO1 and XPO5 interact at the concave surface of the XPO1 but XPO1 binds at the N-terminal whereas XPO5 binds at the $\mathrm{C}$-terminal regions of the XPO1. Interactions are sown in Figure 3K.

\section{XPO5}

XPO5 gene encodes the XPO5 protein (Brownawell \& Macara, 2002). Primarily, it mediates the transport of pre-microRNA from the nucleus to cytoplasm (Yi et al., 2003). A study also suggests that XPO5 is involved in the transport of tRNAs (Gupta et al., 2016). Protein structure investigation revealed that the interior of the XPO5 is hydrophilic in nature whereas exterior is hydrophobic (X. Wang et al., 2011). XPO5 interacts with the Interleukin enhancer-binding factor 3 (ILF3) (Brownawell \& Macara, 2002). Another study showed that alteration in XPO5 expression level could be linked with oncogenesis (Höti et al., 2017). The crystal structure of XPO5 is shown in Figure $1 \mathrm{~L}$.

To form a homodimeric complex (XPO5-XPO5), the two monomers were docked as a receptor and ligand. PIMA and PRODIGY binding energy values $-391.8 \mathrm{~kJ} / \mathrm{mol}$ and $-54.4 \mathrm{~kJ} / \mathrm{mol}$ respectively indicate that XPO5 binds tightly with its monomer and forms a stable complex. The contribution of van der Waals forces to the total stabilization energy is significantly higher than electrostatic interactions. In this complex (Figure $3 \mathrm{~L}$ ), the $\mathrm{C}$-terminal of one monomer binds to the $\mathrm{C}$ - and $\mathrm{N}$-terminals of the other.

\section{Results validation}

To verify the binding energy of 78 docked protein-protein complexes of test proteins, their binding energies were compared with those of experimentally solved complexes (Supplementary Table 3). Comparison shows that the binding energy of docked complexes is slightly higher than the binding energy of experimental complexes. Though the binding energy is evaluated on the basis of number of atomic contacts at the protein-protein interface, other contributory reason for higher energy could be the shorter distances between interacting atoms.

\section{Conclusion}

The primary objective of this study was to predict whether the studied transport proteins have tendency to interact and bind with each other. As it is a fact that in the thronging and dynamic cellular environment, proteins have great many interactions, some of them being random whereas others specific, it is the researchers' desire to dwell into all the possible permutations and combinations of these interactions. Protein-protein binding competition is also distinct possibility. Hence, I investigated protein-protein 
complex formations between the human nuclear transport proteins using various computational tools. In this study, evaluated binding energy of docked complexes indicates that these proteins might have likelihood to bind with each other. This being a primary observation, further experimental evidences are necessary to confirm the above finding. Additionally, I anticipate that this work will be benefitted to the researchers in the future to investigate further studies.

\section{Acknowledgments}

Author is thankful to his chemistry department for providing computational and infrastructure facilities.

\section{Conflicts of Interest}

The author has no conflict of interest to declare.

\section{References}

1. Aladhraei, M., Al-thobhani, A. K., \& Poungvarin, N. (2019). Association of XPO1 Overexpression with NF-KB and Ki67 in Colorectal Cancer. Asian Pacific Journal of Cancer Prevention, 20(12), 3747-3754. https://doi.org/10.31557/APJCP.2019.20.12.3747

2. Baade, I., Spillner, C., Schmitt, K., Valerius, O., \& Kehlenbach, R. H. (2018). Extensive identification and in-depth validation of importin 13 cargoes. Molecular and Cellular Proteomics, 17(7), 1337-1353. https://doi.org/10.1074/mcp.RA118.000623

3. Baas, R., Sijm, A., Van Teeffelen, H. A. A. M., Van Es, R., Vos, H. R., \& Timmers, H. T. M. (2016). Quantitative proteomics of the SMAD (Suppressor of Mothers against Decapentaplegic) transcription factor family identifies importin 5 as a bone morphogenic protein receptor smadspecific importin. Journal of Biological Chemistry, 291(46), 24121-24132. https://doi.org/10.1074/jbc.M116.748582

4. Cortes, P., Ye, ZS., \& Baltimore, D. (1994). RAG-1 interacts with the repeated amino acid motif of the human homologue of the yeast protein SRP1. Proceedings of the National Academy of Sciences of the United States of America, 91(16), 7633-7637, https://doi.org/10.1073/pnas.91.16.7633

5. Bochnakian, A., Zhen, A., Zisoulis, D. G., Idica, A., Kewalramani, V. N., \& Neel, N. (2019). Interferon-Inducible MicroRNA miR-128 Modulates HIV-1 Replication by Targeting TNPO3 mRNA. Journal of Virology, 93(20), 1-15. https://doi.org/10.1128/JVI.00364-19

6. Bonifaci, N., Moroianu, J., Radu, A., \& Blobel, G. (1997). Karyopherin $\beta 2$ mediates nuclear import of a mRNA binding protein. Proceedings of the National Academy of Sciences of the United States of America, 94(10), 5055-5060. https://doi.org/10.1073/pnas.94.10.5055

7. Bono, F., Cook, A. G., Grünwald, M., Ebert, J., \& Conti, E. (2010). Nuclear Import Mechanism of the EJC Component Mago-Y14 Revealed by Structural Studies of Importin 13. Molecular Cell, 37(2), 211-222. https://doi.org/10.1016/j.molcel.2010.01.007

8. Brelstaff, J., Lashley, T., Holton, J. L., Lees, A. J., Rossor, M. N., Bandopadhyay, R., \& Revesz, T. (2011). Transportin1: A marker of FTLD-FUS. Acta Neuropathologica, 122(5), 591-600. https://doi.org/10.1007/s00401-011-0863-6

9. Brooks, B. R., Bruccoleri, R. E., Olafson, B. D., States, D. J., Swaminathan, S., \& Karplus, M. (1983). CHARMM: A program for macromolecular energy, minimization, and dynamics calculations. Journal of Computational Chemistry, 4(2), 187-217. https://doi.org/10.1002/jcc.540040211

10. Brownawell, A. M., \& Macara, I. G. (2002). Exportin-5, a novel karyopherin, mediates nuclear export of double-stranded RNA binding proteins. Journal of Cell Biology, 156(1), 53-64. https://doi.org/10.1083/jcb.200110082

11. Camus, V., Miloudi, H., Taly, A., \& Sola, B. (2017). XPO1 in B cell hematological malignancies: from recurrent somatic mutations to targeted therapy. Journal of Hematology \& Oncology, 10(47), 1-13. https://doi.org/10.1186/s13045-017-0412-4

12. Chao, H. W., Lai, Y. T., Lu, Y. L., Lin, C. L., Mai, W., \& Huang, Y. S. (2012). NMDAR signaling facilitates the IPO5-mediated nuclear import of CPEB3. Nucleic Acids Research, 40(17), 84848498. https://doi.org/10.1093/nar/gks598

13. Chi, N. C., Adam, E. J. H., \& Adam, S. A. (1995). Sequence and characterization of cytoplasmic nuclear protein import factor p97. Journal of Cell Biology, 130(2), 265-274. https://doi.org/10.1083/jcb.130.2.265 
14. Chuang, G. Y., Kozakov, D., Brenke, R., Comeau, S. R., \& Vajda, S. (2008). DARS (Decoys As the Reference State) potentials for protein-protein docking. Biophysical Journal, 95(9), 4217-4227. https://doi.org/10.1529/biophysj.108.135814

15. Cui, W., Wei, Z., Chen, Q., Cheng, Y., Geng, L., Zhang, J., Chen, J., Hou, T., \& Ji, M. (2010). Structure-based design of peptides against G3BP with cytotoxicity on tumor cells. Journal of Chemical Information and Modeling, 50(3), 380-387. https://doi.org/10.1021/ci900404p

16. David, J., Finetti, P., Birnbaum, D., Mamessier, E., \& Bertucci, F. (2019). XPO1 Expression Is a Poor-Prognosis Marker in Pancreatic Adenocarcinoma. Journal of clinical medicine, 8(5), 114. https://doi.org/10.3390/jcm8050596

17. De laco, A., Santoni, F., Vannier, A., Guipponi, M., Antonarakis, S., \& Luban, J. (2013). TNPO3 protects HIV-1 replication from CPSF6-mediated capsid stabilization in the host cell cytoplasm. Retrovirology, 10(20), 1-18. https://doi.org/10.1186/1742-4690-10-20

18. Deane, R., Schäfer, W., Zimmermann, H. P., Mueller, L., Görlich, D., Prehn, S., Ponstingl, H., \& Bischoff, F. R. (1997). Ran-binding protein 5 (RanBP5) is related to the nuclear transport factor importin-beta but interacts differently with RanBP1. Molecular and Cellular Biology, 17(9), 5087-5096. https://doi.org/10.1128/mcb.17.9.5087

19. Deng, T., Engelhardt, O. G., Thomas, B., Akoulitchev, A. V., Brownlee, G. G., \& Fodor, E. (2006). Role of Ran Binding Protein 5 in Nuclear Import and Assembly of the Influenza Virus RNA Polymerase Complex. Journal of Virology, 80(24), 11911-11919. https://doi.org/10.1128/jvi.01565-06

20. Dong, X., Biswas, A., Süel, K. E., Jackson, L. K., Martinez, R., Gu, H., \& Chook, Y. M. (2009). Structural basis for leucine-rich nuclear export signal recognition by CRM1. Nature, 458(7242), 1136-1141. https://doi.org/10.1038/nature07975

21. Dopie, J., Skarp, K. P., Rajakylä, E. K., Tanhuanpää, K., \& Vartiainen, M. K. (2012). Active maintenance of nuclear actin by importin 9 supports transcription. Proceedings of the National Academy of Sciences of the United States of America, 109(9). E544-E552. https://doi.org/10.1073/pnas.1118880109

22. Du, W., Zhu, J., Zeng, Y., Liu, T., Zhang, Y., Cai, T., Fu, Y., Zhang, W., Zhang, R., Liu, Z., \& Huang, J. an. (2020). KPNB1-mediated nuclear translocation of PD-L1 promotes non-small cell lung cancer cell proliferation via the Gas6/MerTK signaling pathway. Cell Death and Differentiation. https://doi.org/10.1038/s41418-020-00651-5

23. Fagerlund, R., Mélen, K., Kinnunen, L., \& Julkunen, I. (2002). Arginine/lysine-rich nuclear localization signals mediate interactions between dimeric STATs and importin alpha 5 . The Journal of Biological Chemistry, 277(33), 30072-30078. https://doi.org/10.1074/jbc.M202943200

24. Fatima, S., Wagstaff, K. M., Lim, S. M., Polo, J. M., Young, J. C., \& Jans, D. A. (2021). The nuclear transporter importin 13 is critical for cell survival during embryonic stem cell differentiation. Biochemical and Biophysical Research Communications, 534, 141-148. https://doi.org/10.1016/j.bbrc.2020.11.099

25. Frey, S., \& Görlich, D. (2007). A Saturated FG-Repeat Hydrogel Can Reproduce the Permeability Properties of Nuclear Pore Complexes. Cell, 130(3), 512-523. https://doi.org/10.1016/j.cell.2007.06.024

26. Fridell, R. A., Truant, R., Thorne, L., Benson, R. E., \& Cullen, B. R. (1997). Nuclear import of hnRNP A1 is mediated by a novel cellular cofactor related to karyopherin- $\beta$. Journal of Cell Science, 110(11), 1325-1331.

27. Fried, H., \& Kutay, U. (2003). Nucleocytoplasmic transport: Taking an inventory. Cellular and Molecular Life Sciences, 60(8), 1659-1688. https://doi.org/10.1007/s00018-003-3070-3

28. Fu, S. C., Huang, H. C., Horton, P., \& Juan, H. F. (2013). ValidNESs: A database of validated leucine-rich nuclear export signals. Nucleic Acids Research, 41(D1), 338-343. https://doi.org/10.1093/nar/gks936

29. Grünwald, M., \& Bono, F. (2011). Structure of Importin13-Ubc9 complex: Nuclear import and release of a key regulator of sumoylation. EMBO Journal, 30(2), 427-438. https://doi.org/10.1038/emboj.2010.320

30. Grünwald, M., Lazzaretti, D., \& Bono, F. (2013). Structural basis for the nuclear export activity of Importin13. EMBO Journal, 32(6), 899-913. https://doi.org/10.1038/emboj.2013.29

31. Gupta, A., Kailasam, S., \& Bansal, M. (2016). Insights into the Structural Dynamics of Nucleocytoplasmic Transport of tRNA by Exportin-t. Biophysical Journal, 110(6), 1264-1279. https://doi.org/10.1016/j.bpj.2016.02.015

32. Henderson, M. J., Russell, A. J., Hird, S., Muñoz, M., Clancy, J. L., Lehrbach, G. M., Calanni, S. T., Jans, D. A., Sutherland, R. L., \& Watts, C. K. W. (2002). EDD, the human hyperplastic 
discs protein, has a role in progesterone receptor coactivation and potential involvement in DNA damage response. Journal of Biological Chemistry, 277(29), 26468-26478. https://doi.org/10.1074/jbc.M203527200

33. Hildebrandt, A., Blossey, R., Rjasanow, S., Kohlbacher, O., \& Lenhof, H. P. (2007). Electrostatic potentials of proteins in water: A structured continuum approach. Bioinformatics, 23(2), 99103. https://doi.org/10.1093/bioinformatics/btl312

34. Höti, N., Yang, S., Aiyetan, P., Kumar, B., Hu, Y., Clark, D., Eroglu, A. U., Shah, P., Johnson, T., Chowdery, W. H., Zhang, H., \& Rodriguez, R. (2017). Overexpression of Exportin-5 Overrides the Inhibitory Effect of miRNAs Regulation Control and Stabilize Proteins via Posttranslation Modifications in Prostate Cancer. Neoplasia (United States), 19(10), 817-829. https://doi.org/10.1016/j.neo.2017.07.008

35. Hu, R. H., Zhang, Z. T., Wei, H. X., Ning, L., Ai, J. S., Li, W. H., Zhang, H., \& Wang, S. Q. (2020). LncRNA ST7-AS1, by regulating miR-181b-5p/KPNA4 axis, promotes the malignancy of lung adenocarcinoma. Cancer Cell International, 20(1), 1-15. https://doi.org/10.1186/s12935-020-01652-7

36. Hurd, T. W., Fan, S., \& Margolis, B. L. (2011). Localization of retinitis pigmentosa 2 to cilia is regulated by importin $\beta 2$. Journal of Cell Science, 124(5), 718-726. https://doi.org/10.1242/jcs.070839

37. Hutten, S., \& Kehlenbach, R. H. (2007). CRM1-mediated nuclear export: to the pore and beyond. Trends in Cell Biology, 17(4), 193-201. https://doi.org/10.1016/j.tcb.2007.02.003

38. Jakel, S. (2002). Importins fulfil a dual function as nuclear import receptors and cytoplasmic chaperones for exposed basic domains. EMBO Journal, 21(3), 377-386. https://doi.org/10.1093/emboj/21.3.377

39. Kahle, J., Baake, M., Doenecke, D., \& Albig, W. (2005). Subunits of the Heterotrimeric Transcription Factor NF-Y Are Imported into the Nucleus by Distinct Pathways Involving Importin $\beta$ and Importin 13. Molecular and Cellular Biology, 25(13), 5339-5354. https://doi.org/10.1128/mcb.25.13.5339-5354.2005

40. Kahler, U., Kamenik, A. S., Waibl, F., Kraml, J., \& Liedl, K. R. (2020). Protein-Protein Binding as a Two-Step Mechanism: Preselection of Encounter Poses during the Binding of BPTI and Trypsin. Biophysical Journal, 119(3), 652-666. https://doi.org/10.1016/j.bpj.2020.06.032

41. Kastritis, P. L., \& Bonvin, A. M. J. J. (2011). Erratum: Are scoring functions in protein - Protein Docking Ready to predict interactomes? Clues from a novel binding affinity benchmark (Journal of Proteome Research (2010) 9 (2216-2225). Journal of Proteome Research, 10(2), 921-922. https://doi.org/10.1021/pr101118t

42. Kataoka, N., Bachorik, J. L., \& Dreyfuss, G. (1999). Transportin-SR, a nuclear import receptor for SR proteins. Journal of Cell Biology, 145(6), 1145-1152. https://doi.org/10.1083/jcb.145.6.1145

43. Kim, J., Mcmillan, E., Kim, H. S., Venkateswaran, N., Makkar, G., Rodriguez-canales, J., Villalobos, P., Neggers, J. E., Mendiratta, S., Wei, S., Landesman, Y., Senapedis, W., Baloglu, E., Chow, C. B., Frink, R. E., Gao, B., Roth, M., Minna, J. D., Daelemans, D., ... White, M. A. (2016). vulnerability in KRAS-mutant lung cancer. Nature Publishing Group. 538(7623), 114117. https://doi.org/10.1038/nature19771

44. Kim, Yong Hak, Ha, S., Kim, J., \& Ham, S. W. (2016). Identification of KPNB1 as a Cellular Target of Aminothiazole Derivatives with Anticancer Activity. ChemMedChem, 11(13), 14061409. https://doi.org/10.1002/cmdc.201600159

45. Kim, Yun Hak, Han, M. E., \& Oh, S. O. (2017). The molecular mechanism for nuclear transport and its application. Anatomy and Cell Biology, 50(2), 77-85. https://doi.org/10.5115/acb.2017.50.2.77

46. Kodama, M., Kodama, T., Newberg, J. Y., Katayama, H., Kobayashi, M., Hanash, S. M., Yoshihara, K., Wei, Z., Tien, J. C., Rangel, R., Hashimoto, K., Mabuchi, S., Sawada, K., Kimura, T., Copeland, N. G., \& Jenkins, N. A. (2017). In vivo loss-of-function screens identify KPNB1 as a new druggable oncogene in epithelial ovarian cancer. Proceedings of the National Academy of Sciences of the United States of America, 114(35), E7301-E7310. https://doi.org/10.1073/pnas.1705441114

47. Köhler, M., Ansieau, S., Prehn, S., Leutz, A., Haller, H., \& Hartmann, E. (1997). Cloning of two novel human importin- $\alpha$ subunits and analysis of the expression pattern of the importin- $\alpha$ protein family. FEBS Letters, 417(1), 104-108. https://doi.org/10.1016/S0014-5793(97)012659

48. Köhler, M., Speck, C., Christiansen, M., Bischoff, F. R., Prehn, S., Haller, H., Görlich, D., \& Hartmann, E. (1999). Evidence for Distinct Substrate Specificities of Importin a Family 
Members in Nuclear Protein Import. Molecular and Cellular Biology, 19(11), 7782-7791. https://doi.org/10.1128/mcb.19.11.7782

49. Koldsø, H., Andersen, O. J., Nikolajsen, C. L., Scavenius, C., Sørensen, C. S., Underhaug, J., Runager, K., Nielsen, N. C., Enghild, J. J., \& Schiøtt, B. (2015). Early Events in the Amyloid Formation of the A546T Mutant of Transforming Growth Factor $\beta$-Induced Protein in Corneal Dystrophies Compared to the Nonfibrillating R555W and R555Q Mutants. Biochemistry, 54(36), 5546-5556. https://doi.org/10.1021/acs.biochem.5b00473

50. Kozakov, D., Hall, D. R., Xia, B., Porter, K. A., Padhorny, D., Yueh, C., Beglov, D., \& Vajda, S. (2017). The ClusPro web server for protein-protein docking. Nature Protocols, 12(2), 255-278. https://doi.org/10.1038/nprot.2016.169

51. Kramer, A., Liashkovich, I., Ludwig, Y., \& Shahin, V. (2008). Atomic force microscopy visualises a hydrophobic meshwork in the central channel of the nuclear pore. Pflugers Archiv European Journal of Physiology, 456(1), 155-162. https://doi.org/10.1007/s00424-007-0396-y

52. Li, D., Fu, S., Wu, Z., Yang, W., Ru, Y., Shu, H., Liu, X., \& Zheng, H. (2019). Erratum: DDX56 inhibits type I interferon by disrupting assembly of IRF3-IPO5 to inhibit IRF3 nucleus import. Journal of Cell Science, 133(5), 1. https://doi.org/10.1242/jcs.244681

53. Li, X. F., Aierken, A. L. D., \& Shen, L. (2020). IPO5 promotes malignant progression of esophageal cancer through activating MMP7. European Review for Medical and Pharmacological Sciences, 24(8), 4246-4254. https://doi.org/10.26355/eurrev_202004_21004

54. Liang, J., Ke, G., You, W., Peng, Z., Lan, J., Kalesse, M., Tartakoff, A. M., Kaplan, F., \& Tao, T. (2008). Interaction between importin 13 and myopodin suggests a nuclear import pathway for myopodin. Molecular and Cellular Biochemistry, 307, 93-100. https://doi.org/10.1007/s11010-007-9588-1

55. Lin, W., Ye, W., Cai, L., Meng, X., Ke, G., Huang, C., Peng, Z., Yu, Y., Golden, J. A., Tartakoff, A. M., \& Tao, T. (2009). The roles of multiple importins for nuclear import of murine aristalessrelated homeobox protein. Journal of Biological Chemistry, 284(30), 20428-20439. https://doi.org/10.1074/jbc.M109.004242

56. Liu, L., McBride, K. M., \& Reich, N. C. (2005). STAT3 nuclear import is independent of tyrosine phosphorylation and mediated by importin-a3. Proceedings of the National Academy of Sciences of the United States of America, 102(23), 8150-8155. https://doi.org/10.1073/pnas.0501643102

57. Maertens, G. N., Cook, N. J., Wang, W., Hare, S., Gupta, S. S., Öztop, I., Lee, K. E., Pye, V. E., Cosnefroy, O., Snijders, A. P., Ramani, V. N. K., Fassati, A., Engelman, A., \& Cherepanov, P. (2014). Structural basis for nuclear import of splicing factors by human Transportin 3. Proceedings of the National Academy of Sciences of the United States of America, 111(7), 2728-2733. https://doi.org/10.1073/pnas.1320755111

58. Mathew, O., \& Sowdhamini, R. (2016). PIMA: Protein-Protein Interactions in Macromolecular Assembly - a web server for its Analysis and Visualization. Bioinformation, 12(1), 9-11. https://doi.org/10.6026/97320630012009

59. Matsumiya, T., Xing, F., Ebina, M., Hayakari, R., Imaizumi, T., Yoshida, H., Kikuchi, H., Topham, M. K., Satoh, K., \& Stafforini, D. M. (2013). Novel Role for Molecular Transporter Importin 9 in Posttranscriptional Regulation of IFN- $\varepsilon$ Expression. The Journal of Immunology, 191(4), 1907-1915. https://doi.org/10.4049/jimmunol.1201925

60. Miloudi, H., Bohers, É., Guillonneau, F., Taly, A., Gibouin, V. C., Viailly, P., Jego, G., Grumolato, L., Jardin, F., \& Sola, B. (2020). XPO1E571K Mutation Modifies Exportin 1 Localisation and Interactome in B-Cell Lymphoma. Cancers, 12(10), 1-20. https://doi.org/10.3390/cancers1210282

61. Mingot, J. M., Kostka, S., Kraft, R., Hartmann, E., \& Görlich, D. (2001). Importin 13: A novel mediator of nuclear import and export. EMBO Journal, 20(14), 3685-3694. https://doi.org/10.1093/emboj/20.14.3685

62. Mottin, M., Souza, P. C. T., \& Skaf, M. S. (2015). Molecular Recognition of PPARy by Kinase Cdk5/p25: Insights from a Combination of Protein-Protein Docking and Adaptive Biasing Force Simulations. Journal of Physical Chemistry B, 119(26), 8330-8339. https://doi.org/10.1021/acs.jpcb.5b04269

63. Okada, N., Ishigami, Y., Suzuki, T., Kaneko, A., Yasui, K., Fukutomi, R., \& Isemura, M. (2008). Importins and exportins in cellular differentiation. Journal of Cellular and Molecular Medicine, 12(5B), 1863-1871. https://doi.org/10.1111/j.1582-4934.2008.00437.x

64. Padavannil, A., Sarkar, P., Kim, S. J., Cagatay, T., Jiou, J., Brautigam, C. A., Tomchick, D. R., Sali, A., D'Arcy, S., \& Chook, Y. M. (2019). Importin-9 wraps around the H2A-H2B core to act as nuclear importer and histone chaperone. ELife, 8, 1-24. https://doi.org/10.7554/eLife.43630 
bioRxiv preprint doi: https://doi.org/10.1101/2021.03.22.436462; this version posted March 22, 2021. The copyright holder for this preprint (which was not certified by peer review) is the author/funder, who has granted bioRxiv a license to display the preprint in perpetuity. It is made available under aCC-BY-NC-ND 4.0 International license.

65. Panté, N., \& Kann, M. (2002). Nuclear pore complex is able to transport macromolecules with diameters of $\sim 39 \mathrm{~nm}$. Molecular Biology of the Cell, 13(2), 425-434. https://doi.org/10.1091/mbc.01-06-0308

66. Percipalle, P., Clarkson, D. W., Kent, H. M., Rhodes, D., \& Stewart, M. (1997). Molecular interactions between the importin $\alpha / \beta$ heterodimer and proteins involved in vertebrate nuclear protein import. Journal of Molecular Biology, 266(4), 722-732. https://doi.org/10.1006/jmbi.1996.0801

67. Pollard, V. W., Michael, W. M., Nakielny, S., Siomi, M. C., Wang, F., \& Dreyfuss, G. (1996). A novel receptor-mediated nuclear protein import pathway. Cell, 86(6), 985-994. https://doi.org/10.1016/S0092-8674(00)80173-7

68. Qiao, B., Lopez, L., \& Olvera De La Cruz, M. (2019). "Mirror"-like Protein Dimers Stabilized by Local Heterogeneity at Protein Surfaces. Journal of Physical Chemistry B, 123(18), 3907-3915. https://doi.org/10.1021/acs.jpcb.9b01394

69. Radstake, T. R. D. J., Gorlova, O., Rueda, B., Martin, J. E., Alizadeh, B. Z., Palomino-Morales, R., Coenen, M. J., Vonk, M. C., Voskuyl, A. E., Schuerwegh, A. J., Broen, J. C., Van Riel, P. L. C. M., Van 'T Slot, R., Italiaander, A., Ophoff, R. A., Riemekasten, G., Hunzelmann, N., Simeon, C. P., Ortego-Centeno, N., ... Mayes, M. D. (2010). Genome-wide association study of systemic sclerosis identifies CD247 as a new susceptibility locus. Nature Genetics, 42(5), 426-429. https://doi.org/10.1038/ng.565

70. Rice, B. L., Stake, M. S., \& Parent, L. J. (2020). TNPO3-mediated nuclear entry of the Rous sarcoma virus Gag protein is independent of the cargo-binding domain. Journal of Virology, 94(17), 1-13. https://doi.org/10.1101/2020.03.12.989608

71. Sachse, S. M., Lievens, S., Ribeiro, L. F., Dascenco, D., Masschaele, D., Horré, K., Misbaer, A., Vanderroost, N., De Smet, A. S., Salta, E., Erfurth, M., Kise, Y., Nebel, S., Van Delm, W., Plaisance, S., Tavernier, J., De Strooper, B., De Wit, J., \& Schmucker, D. (2019). Nuclear import of the DSCAM -cytoplasmic domain drives signaling capable of inhibiting synapse formation . The EMBO Journal, 38(6), 1-19. https://doi.org/10.15252/embj.201899669

72. Schrödinger LLC. (2010). The PyMOL molecular graphics system. Version 2.4.1

73. Seki, T., Tada, S., Katada, T., \& Enomoto, T. (1997). Cloning of a cDNA encoding a novel importin- $\alpha$ homologue, Qip1: Discrimination of Qip1 and Rch1 from hSrp1 by their ability to interact with DNA helicase Q1/RecQL. Biochemical and Biophysical Research Communications, 234(1), 48-53. https://doi.org/10.1006/bbrc.1997.6535

74. Sekimoto, N., Suzuki, Y., \& Sugano, S. (2017). Decreased KPNB1 expression is induced by PLK1 inhibition and leads to apoptosis in lung adenocarcinoma. Journal of Cancer, 8(19), 4125-4140. https://doi.org/10.7150/jca.21802

75. Soulier, J. L., Russo, O., Giner, M., Rivail, L., Berthouze, M., Ongeri, S., Maigret, B., Fischmeister, R., Lezoualc'h, F., Sicsic, S., \& Berque-Bestel, I. (2005). Design and synthesis of specific probes for human 5-HT4 receptor dimerization studies. Journal of Medicinal Chemistry, 48(20), 6220-6228. https://doi.org/10.1021/jm050234z

76. Ström, A., \& Weis, K. (2001). Importin-beta-like nuclear transport receptors. Genome Biology, 2, 1-9. https://doi.org/10.1186/gb-2001-2-6-reviews3008

77. Sun, Z., Wu, T., Zhao, F., Lau, A., Birch, C. M., \& Zhang, D. D. (2011). KPNA6 (Importin 7)Mediated Nuclear Import of Keap1 Represses the Nrf2-Dependent Antioxidant Response. Molecular and Cellular Biology, 31(9), 1800-1811. https://doi.org/10.1128/mcb.05036-11

78. Swale, C., Da Costa, B., Sedano, L., Garzoni, F., McCarthy, A. A., Berger, I., Bieniossek, C., Ruigrok, R. W. H., Delmas, B., \& Crépin, T. (2020). X-ray Structure of the Human Karyopherin RanBP5, an Essential Factor for Influenza Polymerase Nuclear Trafficking. Journal of Molecular Biology, 432(10), 3353-3359. https://doi.org/10.1016/j.jmb.2020.03.021

79. Valdés, H., Díaz, N., Suárez, D., \& Fernández-Recio, J. (2010). Interdomain conformations in the full-length MMP-2 enzyme explored by protein-protein docking calculations using pyDock. Journal of Chemical Theory and Computation, 6(7), 2204-2213. https://doi.org/10.1021/ct100097x

80. Valle-Casuso, J. C., Di Nunzio, F., Yang, Y., Reszka, N., Lienlaf, M., Arhel, N., Perez, P., Brass, A. L., \& Diaz-Griffero, F. (2012). TNPO3 Is Required for HIV-1 Replication after Nuclear Import but prior to Integration and Binds the HIV-1 Core. Journal of Virology, 86(10), 5931-5936. https://doi.org/10.1128/jvi.00451-12

81. Vangone, A., \& Bonvin, A. M. J. J. (2015). Contacts-based prediction of binding affinity in protein-protein complexes. ELife, 4, 1-15. https://doi.org/10.7554/eLife.07454

82. Vascon, F., Gasparotto, M., Giacomello, M., Cendron, L., Bergantino, E., Filippini, F., \& Righetto, I. (2020). Protein electrostatics: From computational and structural analysis to 
discovery of functional fingerprints and biotechnological design. Computational and Structural Biotechnology Journal, 18, 1774-1789. https://doi.org/10.1016/j.csbj.2020.06.029

83. Walker, P., Doenecke, D., \& Kahle, J. (2009). Importin 13 mediates nuclear import of histone fold-containing chromatin accessibility complex heterodimers. Journal of Biological Chemistry, 284(17), 11652-11662. https://doi.org/10.1074/jbc.M806820200

84. Wang, T., Huang, Z., Huang, N., Peng, Y., Gao, M., Wang, X., \& Feng, W. (2019). Inhibition of KPNB1 inhibits proliferation and promotes apoptosis of chronic myeloid leukemia cells through regulation of E2F1. OncoTargets and Therapy, 12, 10455-10467. https://doi.org/10.2147/OTT.S210048

85. Wang, X., Xu, X., Ma, Z., Huo, Y., Xiao, Z., Li, Y., \& Wang, Y. (2011). Dynamic mechanisms for pre-miRNA binding and export by Exportin-5. RNA, 17(8), 1511-1528. https://doi.org/10.1261/rna.2732611

86. Xu, X., Zhang, X., Xing, H., Liu, Z., Jia, J., Jin, C., \& Zhang, Y. (2019). Importin-4 functions as a driving force in human primary gastric cancer. Journal of Cellular Biochemistry, 120(8), 12638-12646. https://doi.org/10.1002/jcb.28530

87. Xue, L. C., Rodrigues, J. P., Kastritis, P. L., Bonvin, A. M., \& Vangone, A. (2016). PRODIGY: A web server for predicting the binding affinity of protein-protein complexes. Bioinformatics, 32(23), 3676-3678. https://doi.org/10.1093/bioinformatics/btw514

88. Yang, J., Lu, C., Wei, J., Guo, Y., Liu, W., Luo, L., Fisch, G., \& Li, X. (2017). Inhibition of KPNA4 attenuates prostate cancer metastasis. Oncogene, 36(20), 2868-2878. https://doi.org/10.1038/onc.2016.440

89. Yang, Jian, Guo, Y., Lu, C., Zhang, R., Wang, Y., Luo, L., Zhang, Y., Chu, C. H., Wang, K. J., Obbad, S., Yan, W., \& Li, X. (2019). Inhibition of Karyopherin beta 1 suppresses prostate cancer growth. Oncogene, 38(24), 4700-4714. https://doi.org/10.1038/s41388-019-0745-2

90. Yang, Z., Bogdan, P., \& Nazarian, S. (2021). An in silico deep learning approach to multiepitope vaccine design: a SARS-CoV-2 case study. Scientific Reports, 11(1), 1-21. https://doi.org/10.1038/s41598-021-81749-9

91. Yasuhara, N., Oka, M., \& Yoneda, Y. (2009). The role of the nuclear transport system in cell differentiation. Seminars in Cell and Developmental Biology, 20(5), 590-599. https://doi.org/10.1016/j.semcdb.2009.05.003

92. Yi, R., Qin, Y., Macara, I. G., \& Cullen, B. R. (2003). Exportin-5 mediates the nuclear export of pre-microRNAs and short hairpin RNAs. Genes and Development, 17(24), 3011-3016. https://doi.org/10.1101/gad.1158803

93. Zhang, M., Luo, H., \& Hui, L. (2019). MiR-3619-5p hampers proliferation and cisplatin resistance in cutaneous squamous-cell carcinoma via KPNA4. Biochemical and Biophysical Research Communications, 513(2), 419-425. https://doi.org/10.1016/j.bbrc.2019.03.203

94. Zhang, W., Lu, Y., Li, X., Zhang, J., Lin, W., Zhang, W., Zheng, L., \& Le, X. (2019). IPO5 promotes the proliferation and tumourigenicity of colorectal cancer cells by mediating RASAL2 nuclear transportation. Journal of Experimental and Clinical Cancer Research, 38(1), 1-14. https://doi.org/10.1186/s13046-019-1290-0

95. Zhou, Y., Liu, F., Xu, Q., Yang, B., Li, X., Jiang, S., Hu, L., Zhang, X., Zhu, L., Li, Q., Zhu, X., Shao, H., Dai, M., Shen, Y., Ni, B., Wang, S., Zhang, Z., \& Teng, Y. (2020). Inhibiting Importin 4-mediated nuclear import of CEBPD enhances chemosensitivity by repression of PRKDCdriven DNA damage repair in cervical cancer. Oncogene, 39(34), 5633-5648. https://doi.org/10.1038/s41388-020-1384-3

96. Zhu, Z. C., Liu, J. W., Li, K., Zheng, J., \& Xiong, Z. Q. (2018). KPNB1 inhibition disrupts proteostasis and triggers unfolded protein response-mediated apoptosis in glioblastoma cells. Oncogene, 37(22), 2936-2952. https://doi.org/10.1038/s41388-018-0180-9 